\title{
Administrative Information
}

Award Number:

Project Title:

Project Period:

Recipient Organization: The University of Alabama, Tuscaloosa, AL 35487-0202, USA.

Principal Investigator: ～Dr. Ramana G. Reddy, (205) 348-4246, rreddy@eng.ua.edu

Business Contact: $\quad$ Cynthia Hope, (205) 348-5152, chope@fa.ua.edu

DOE Project Officer: Gibson Asuquo, 303-275-4910, gibson.asuquo@go.doe.gov

DOE Project Monitor: $\quad$ Kristen McDaniel, 720-356-1285, kristen.mcdaniel@go.doe.gov

DOE HQ Contact: $\quad$ Dickson Ozokwelu, 202-586-8501, dickson.ozokwelu@hq.doe.gov

DOE Contract Specialist: Christina Kouch, 303-275-6045, christina.kouch@ go.doe.gov

\section{Authorized Distribution Limitation Notice:}

All information submitted in this report is public information. This report may be posted on the appropriate sub-program website, minus budget information. 


\section{Executive Summary}

\section{(i) How the research adds to the understanding of the area investigated:}

There are three steps involved in accomplishing the final goal of "Reduction of Metal Oxide to Metal Using Ionic Liquids". They are:

(i) Dissolution of metal oxide in an ionic liquid

(ii) Determination of reduction potential using cyclic voltammetry (CV)

(iii) Reduction of the dissolved metal oxide.

In each and every step of the process, more than one process variable has been examined. In the dissolution step, the effect of temperature, time and the amount of metal oxide has been estimated. The effect of changing the working electrode has been tested while determining the reduction potential using CV. Last but not the least, the effect of stirring, reduction potential, time, temperature, and the amount of metal oxide dissolved on the current efficiency and energy consumption of the process has been investigated. The final products obtained were characterized using X-ray diffraction (XRD) for phases present and scanning electron microscopy (SEM) equipped with energy dispersive spectrometer (EDS) for the determination of morphological features and elemental analysis.

\section{(ii) Technical effectiveness and economic feasibility of the methods or techniques investigated or demonstrated:}

The technique used, namely, electro-deposition using ionic liquids, is highly effective with a strong technical background. The dissolved metal oxide forms a complex with the ionic liquid and/or the complexing agent such as urea. The complexed metal ion does not precipitate or segregate out of the solution, thus providing highly stable liquid, provided the temperature is unaltered. The stability of the solution is maintained during and after electro-deposition.

In most of the electro-deposition processes, the major cost of operation is from the current efficiency during the process. The current efficiencies are relatively high in the systems investigated and highest values were $86.7 \%$ for $\mathrm{Pb}$ and $95.6 \%$ for $\mathrm{Zn}$. 
(iii) How the project is otherwise of benefit to the public:

The public will directly benefit from this proposed technique by the low, non-toxic emissions to the environment. Indirect benefits are the low cost of parts made from these metals produced using ionic liquids. The reduction in the cost of phase pure raw material will substantially reduce the cost of the parts made out of these metals. In summary, the method of electro-reduction using ionic liquids is not only cost effective, but also environment friendly. 
Acknowledgment: "This report is based upon work supported by the U. S. Department of Energy under Award No. DE-EE0003459".

Disclaimer: "Any findings, opinions, and conclusions or recommendations expressed in this report are those of the author(s) and do not necessarily reflect the views of the Department of Energy" 


\section{Table of Contents}

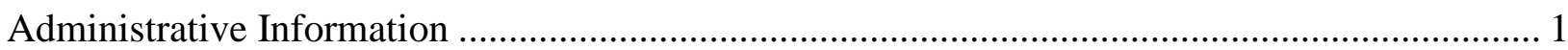

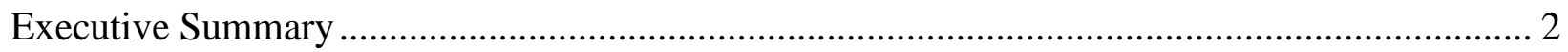

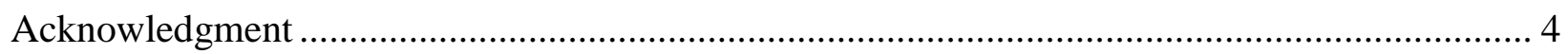

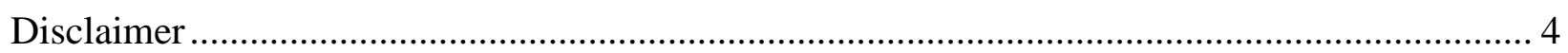

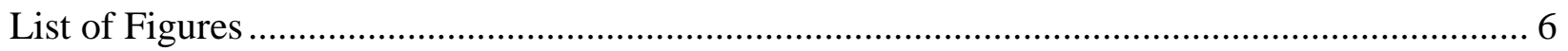

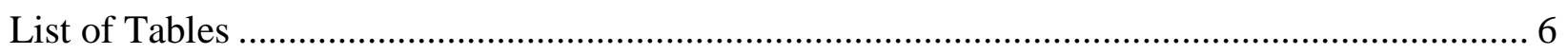

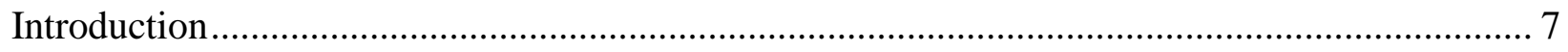

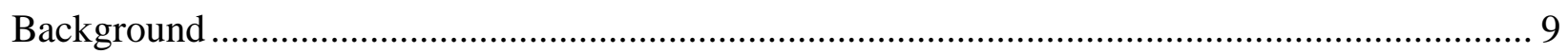

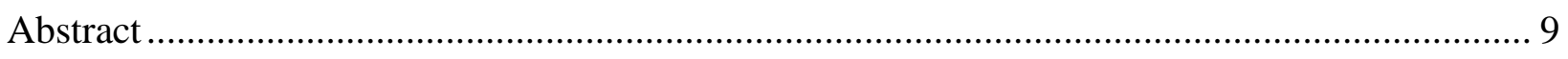

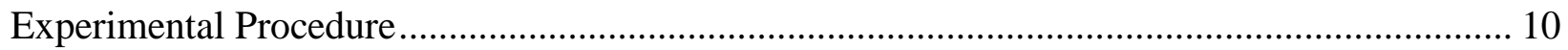

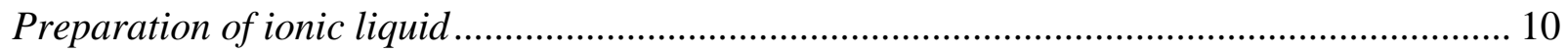

Dissolution of metal oxide in 2:1 Urea/ChCl ionic liquid .................................................. 11

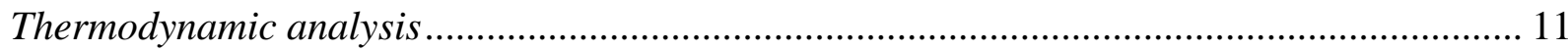

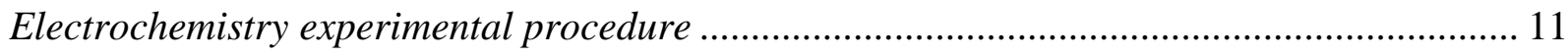

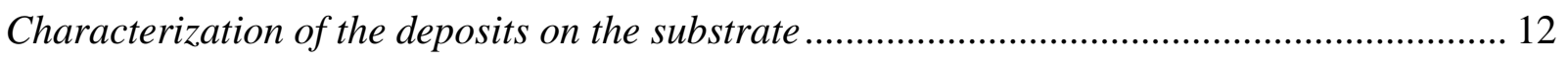

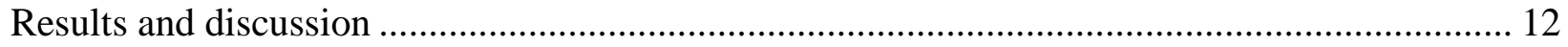

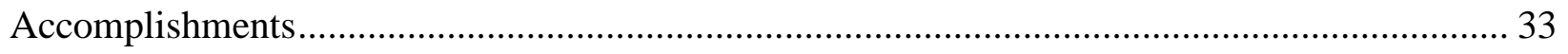

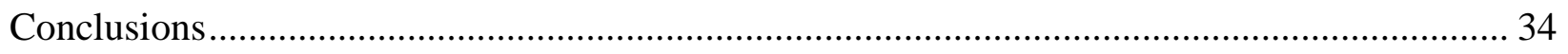

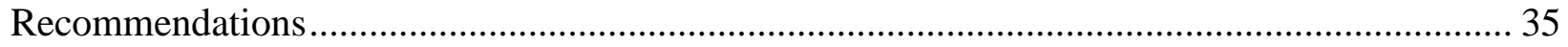

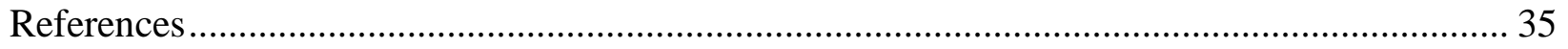




\section{List of Figures}

Figure 1: $\quad$ Urea and $\mathrm{ChCl}$ eutectic mixture in a molar ratio $2: 1$ heating for 12 hours at $90^{\circ} \mathrm{C} \ldots \ldots \ldots \ldots . . . .11$

Figure 2: Infrared spectrum for 2:1 Urea/Choline Chloride mixed for 12 hours at $90^{\circ} \mathrm{C} \ldots \ldots \ldots \ldots \ldots \ldots . . . . . . .13$

Figure 3a: Infrared spectrum with addition of lead oxide in $30 \mathrm{~mL} 2: 1$ Urea/ $\mathrm{ChCl}$ eutectic mixture in a temperature of $90^{\circ} \mathrm{C}$, green line was getting from the eutectic mixture with dissolving $0.3 \mathrm{~g} \mathrm{PbO}$ compared to the red line which was obtained from the 2:1 Urea and $\mathrm{ChCl}$ eutectic mixture

Figure 3b: Infrared spectrum with addition of zinc oxide in $30 \mathrm{~mL} \mathrm{2:1} \mathrm{Urea/ChCl} \mathrm{eutectic}$ mixture in a temperature of $90^{\circ} \mathrm{C}$

Figure 5: Effect of amount of lead oxide addition on its dissolution in $30 \mathrm{~mL} 2: 1$ molar ratio of Urea and $\mathrm{ChCl}$ ionic liquid for 20 hours in a temperature of $90^{\circ} \mathrm{C}$

Figure 6: Effect of temperature on the dissolution of $0.5 \mathrm{~g}$ lead oxide in $30 \mathrm{~mL} 2: 1$ molar ratio of Urea and $\mathrm{ChCl}$ ionic liquid for 20 hours

Figure 7: Eh-pH diagram for morality $0.0417 \mathrm{~mol} / \mathrm{kg}$ lead in $30 \mathrm{~mL} \mathrm{2:1} \mathrm{molar} \mathrm{ratio} \mathrm{of} \mathrm{Urea}$ and $\mathrm{ChCl}$ eutectic mixture (at $\left.90^{\circ} \mathrm{C}, 1 \mathrm{~atm}\right)$

Figure 10: Electro-deposition of $0.3 \mathrm{~g} \mathrm{PbO}$ in $30 \mathrm{~mL} \mathrm{2:1} \mathrm{molar} \mathrm{ratio} \mathrm{of} \mathrm{Urea} \mathrm{and} \mathrm{ChCl}$ eutectic mixture on $\mathrm{Cu}$ electrode at fixed potential $\mathrm{E}^{\mathrm{o}}=-2.0 \mathrm{~V}$ in a solution with constant

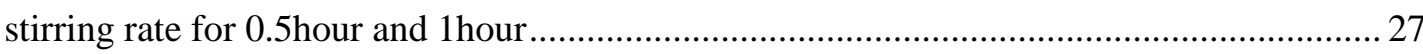

Figure 11a: X-ray diffraction (XRD) pattern for Lead deposits on copper working electrode................. 29

Figure 11b: X-ray diffraction (XRD) pattern for Zinc deposits on Aluminum sheet working electrode

Figure 12a: Scanning Electron Microscopy showing different region of the lead deposits on $\mathrm{Cu}$ foil obtained from a molar ratio of 2:1 urea and choline chloride eutectic mixture and Energy Dispersive Electron analysis of the lead deposits.

Figure 12b: SEM micrograph of the zinc deposits in different region on aluminum sheet grown from 2:1 molar ratio of urea and choline chloride eutectic mixture and Energy Dispersive Electron analysis of zinc deposits.

\section{List of Tables}

Table I: $\quad$ Solubility of metal oxide in 2:1 molar ratio of Urea and $\mathrm{ChCl}$ in a temperature of

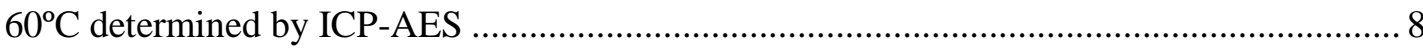

Table II. Standard infrared absorption of stretching and bond variations for different

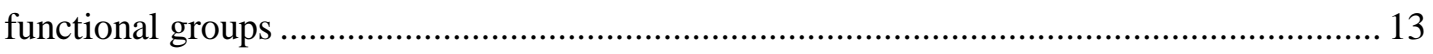

Table III: Experimental conditions for the electro-deposition of $\mathrm{Pb}$ from $\mathrm{PbO}$................................... 23

Table IV. Experimental results calculated for $0.3 \mathrm{~g} \mathrm{PbO}$ in $30 \mathrm{~mL}$ urea based ionic liquid which conducted for $\mathrm{t}=0.5 \mathrm{hr}, 1 \mathrm{hr}$ for fixed potential $\mathrm{E}_{1}^{\mathrm{o}}=-1.8 \mathrm{~V}$ and $\mathrm{E}_{2}^{\mathrm{o}}=-2.0 \mathrm{~V}$, in a solution

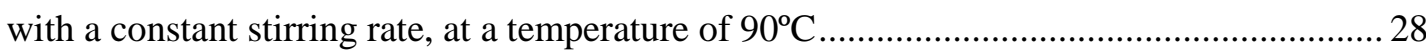

Table V. Current efficiency calculation of zinc oxide for different parameters, $\mathrm{E}^{\mathrm{o}}=-1.6 \mathrm{~V}$, $1.7 \mathrm{~V}$, and $-1.9 \mathrm{~V}$; amount $=1.0 \mathrm{~g}, 2.0 \mathrm{~g}$, and $3.0 \mathrm{~g}$; temperature $=60^{\circ}, 100^{\circ}$, and $120^{\circ}$, fixed time at 4 hours in a non-stirring solution................................................................ 28

Table VI: Comparison of the actual accomplishments with the goals and objectives of the project 


\section{Introduction}

Due to the limitation of the environment was becoming increasingly rigid, inorganic reactions, separation and extraction technologies demand the requirement of alternative solvents that should have (i) non measurable vapor pressure; (ii) non-flammable and non-corrosive; (iii) wide liquid range; (iv) thermo-stability.

Based on these requirements of the new green solvent, water was being used for a reaction media [1]. While its low miscibility with organic substrates restricts the application of water as a solvent in organic industry. Thus further modification of water and investigation of a more suitable green solvent become an urgent task for scientist. Most recently, ionic liquids were being recognized as novel pathway for dissolving organic and inorganic substrates. A lot of applications such as solvents for organic and catalytic reactions, electrolytes for electrochemical processes, solvents for extraction and separation processes were being investigated by using ionic liquids [2]. Different from other traditional molecular solvent that are composed of neutral species, ILs are materials that only composed of anions and cations [3]. Solvent polarity has a significant impact on the result of the reaction. In the case of ionic liquids solvent, many interactions are involved in the process. Some investigation results demonstrate that using solvatochromic dyes to discover solvent-solute interactions in the ionic liquids [4]. The nucleophilicity makes the ionic liquid unique due to its only dependence of anion and lower nucleophilicity than that of polar solvents. It is reported that there are two generations of ILs: (i) cation and anion combined with complexion agent reacts into cation and complex anion; (ii) Cation and $\mathrm{Cl}^{-}$mixed with urea react into $\mathrm{Cat}^{+}$and $\mathrm{Cl}^{-}$. urea. [5] The conductivity of ILs enables the extraction of metal from metal oxide an economically viable pathway. Early chloroaluminate ionic liquids e.g. $\mathrm{AlCl}_{3}$ and 1-methyl-3-butyl-imidazolium chloride (BMIC) have already been successfully used as solvent in extraction of metals [6]. However due to availability and toxicity of these ionic liquids, their practical applications for large scale production of some metals have been limited. An alternative way to make ionic liquid is to mix a simple quaternary ammonium with halide. These eutectic mixtures can be described as a formula: $R_{1} R_{2} R_{3} R_{4} N^{+} X$. $z$ Y. Y can be described as a complexion agent such as $\mathrm{MCl}_{\mathrm{X}}$ or $\mathrm{RCONH}_{2}$. Few studies have been carried out by using $\mathrm{RCONH}_{2}$ type ionic liquid which has a hydrogen bond donor as the 
complexion agents [7]. Urea $\left(\mathrm{CO}\left(\mathrm{NH}_{2}\right)_{2}\right)$ and choline chloride $\left(\mathrm{C}_{5} \mathrm{H}_{14} \mathrm{ClNO}\right)$ or $\mathrm{ChCl}$ eutectic mixture has been investigated as an electrolyte for metal extraction process. The melting point of choline chloride was reported at $302^{\circ} \mathrm{C}$ (decomposes) while melting point of urea was reported at $133-135^{\circ} \mathrm{C}$. Based on theories that (1) mixture of two compounds that has the lowest melting point; (2) depression of freezing point related to the strength of interaction between the two components,[8] the molar ratio $2: 1 \mathrm{Urea} / \mathrm{ChCl}$ eutectic mixture has been reported that can be mixed into liquid at a specific temperature range $60-100^{\circ} \mathrm{C}$ [9]. Low temperature molten salt also shows its capability for dissolving different metal oxide. Solubility data for different metal oxide such as $\mathrm{ZnO}, \mathrm{Cu}_{2} \mathrm{O}$ has been reported in recent paper. Basically the showing of high solubility in the ionic liquid is derived from the capability of forming $\mathrm{H}$ bonds. It is exhibited that low temperature molten salts have a comparable solubility with high temperature molten salts. Table I exhibits part of metal oxide solubility in 2:1 molar ratio of urea and choline chloride eutectic mixture at $60^{\circ} \mathrm{C}$. Results are measured by Inductively Coupled Plasma Atomic Emission Spectroscopy (ICP-AES).

Table I: Solubility of metal oxide in 2:1 molar ratio of Urea and $\mathrm{ChCl}$ in a temperature of $60^{\circ} \mathrm{C}$ determined by ICP-AES

\begin{tabular}{cr}
\hline Metal Oxide & Solubility/ppm \\
\hline $\mathrm{ZnO}$ & 8466 \\
$\mathrm{Cu}$ & $\mathrm{O}$ \\
$\mathrm{CuO}$ & 8725 \\
$\mathrm{PbO}_{2}$ & 470 \\
$\mathrm{Al}_{2} \mathrm{O}_{3}$ & 9157 \\
$\mathrm{MnO}_{2}$ & $<1$ \\
$\mathrm{Fe}_{2} \mathrm{O}_{3}$ & 493 \\
$\mathrm{Fe}_{3} \mathrm{O}_{4}$ & 49 \\
\hline
\end{tabular}

The ionic liquid which is composed of urea and choline chloride in a molar ration 2:1 was used to extract zinc from zinc oxide and lead from lead oxide. The attractive feature of this type of ionic liquid is its relatively high viscosity. The object of this work is to investigate the metal solubility in this ionic liquid under different temperature, time period and by different amount. Systematic understanding of electro-deposition process is interpreted in terms of cyclic voltammetry and chronoamperimetric experiment. Clear illustration of metal deposits was obtained on the substrates not only on the polycrystalline aluminum but also on inert substrates such as copper and platinum. 


\title{
Background
}

\section{(i) Original hypotheses:}

First, we assume that most metal oxide can be successfully dissolved in selected ionic liquids (e.g. Urea and choline chloride based eutectic mixture) and the solubility can be easily tested by Inductively Coupled Plasma Atomic Emission Spectroscopy (ICP-AES). Thus FTIR was being used for testing the chemical bonds as well as bond strength between metal and Nitrile group (R$\mathrm{C} \equiv \mathrm{N})$ and functional group $\left(\mathrm{R}-\mathrm{N}^{+} \equiv \mathrm{N}\right)$ in the solution before and after dissolution. Second, we assume that there is only one set of redox reaction happened during the cyclic voltammetry which will correspond to the oxidation and the reduction of the metal ions of interest. Last but not the least, any inert metal can be used as working electrode.

\section{(ii) Problems encountered:}

In the first hypothesis, ICP-AES cannot be used to quantify the solubility of the metal oxide in the solution due to high viscosity of the urea and choline chloride eutectic mixture. We tried to dilute the ionic liquid by using $\mathrm{HNO}_{3}$ but the immiscibility of ionic liquid in inorganic solution makes it not a feasible way. Then we tried to use FTIR to obtain a comparable peak change under different process variables such as temperature, amount and time. In the second hypothesis, two sets of redox reaction happened during the cyclic voltammetry for lead. The species in the solution cannot be testified due to the limitation of the instrument e.g. FAB mass spectra. In the last hypothesis, many inert metal had been examined that cannot be used as working electrode, most are from IV-B in the period table such as Ti, Zr.

\begin{abstract}
A novel pathway for the high efficiency production of metal from metal oxide means of electrolysis in ionic liquids at low temperature was investigated. The main emphasis was to eliminate the use of carbon and high temperature application in the reduction of metal oxides to metals. The emphasis of this research was to produce metals such as $\mathrm{Zn}$, and $\mathrm{Pb}$ that are normally produced by the application of very high temperatures. The reduction of zinc oxide to
\end{abstract}


zinc and lead oxide to lead were investigated. This study involved three steps in accomplishing the final goal of reduction of metal oxide to metal using ionic liquids: 1) Dissolution of metal oxide in an ionic liquid, 2) Determination of reduction potential using cyclic voltammetry (CV) and 3) Reduction of the dissolved metal oxide. Ionic liquids provide additional advantage by offering a wide potential range for the deposition. In each and every step of the process, more than one process variable has been examined. Experimental results for electrochemical extraction of $\mathrm{Zn}$ from $\mathrm{ZnO}$ and $\mathrm{Pb}$ from $\mathrm{PbO}$ using eutectic mixtures of Urea $\left(\left(\mathrm{NH}_{2}\right)_{2} \mathrm{CO}\right)$ and Choline chloride $\left(\mathrm{HOC}_{2} \mathrm{H}_{4} \mathrm{~N}\left(\mathrm{CH}_{3}\right)_{3}{ }^{+} \mathrm{Cl}^{-}\right)$or $(\mathrm{ChCl})$ in a molar ratio 2:1, varying voltage and temperatures were carried out. Fourier Transform Infra-Red (FTIR) spectroscopy studies of ionic liquids with and without metal oxide additions were conducted. FTIR and induction coupled plasma spectroscopy (ICPS) was used in the characterization of the metal oxide dissolved ionic liquid. Electrochemical experiments were conducted using EG\&G potentiostat/galvanostat with three electrode cell systems. Cyclic voltammetry was used in the determination of reduction potentials for the deposition of metals. Chronoamperometric experiments were carried out in the potential range of $-0.6 \mathrm{~V}$ to $-1.9 \mathrm{~V}$ for lead and $-1.4 \mathrm{~V}$ to $-1.9 \mathrm{~V}$ for zinc. The deposits were characterized using XRD and SEM-EDS for phase, morphological and elemental analysis. The results showed that pure metal was deposited on the cathode. Successful extraction of metal from metal oxide dissolved in Urea/ChCl (2:1) was accomplished. The current efficiencies were relatively high in both the metal deposition processes with current efficiency greater than $86 \%$ for lead and $95 \%$ for zinc. This technology will advance the metal oxide reduction process by increasing the process efficiency and also eliminate the production of $\mathrm{CO}_{2}$ which makes this an environmentally benign technology for metal extraction.

\section{Experimental Procedure}

\section{Preparation of ionic liquid}

The electrolyte was prepared by heating up the urea $\left(\mathrm{CO}\left(\mathrm{NH}_{2}\right)_{2}\right)($ Alfa Aesar 99.3\%) and choline chloride $\left(\mathrm{C}_{5} \mathrm{H}_{14} \mathrm{ClNO}\right)(\mathrm{ChCl})($ Alfa Aesar $98 \%)$ which is mixed in a molar ratio of 2:1 at about $90^{\circ} \mathrm{C}$ for 12 hours with constant stirring in the solution. A clear homogeneous solution was obtained (Figure 1). 


\section{Dissolution of metal oxide in 2:1 Urea/ChCl ionic liquid}

Different amounts of lead oxide(Alfa Aesar, ACS, 99.0\%) and zinc oxide (Fisher Scientific, certified ACS) were dissolved in the 2:1 Urea/ $\mathrm{ChCl}$ eutectic mixture between the temperatures of $70-100^{\circ} \mathrm{C}$ with constant stirring. Solution containing dissolved lead and zinc oxide was compared to that before the dissolution. Results are obtained from Fourier Transform Infrared Spectroscopy (FTIR), model Perkin Elmer spectrum 400. Lead oxide and zinc oxide were dissolved for 24 hours, at a temperature of $90^{\circ} \mathrm{C}$, and with constant stirring.

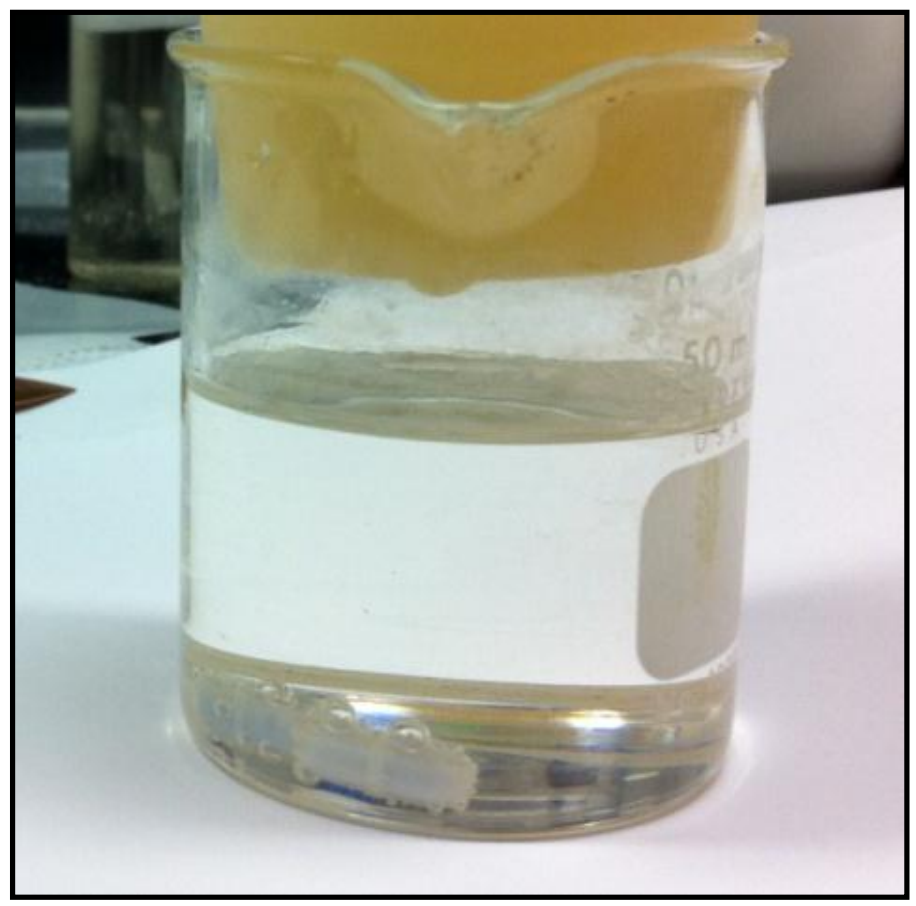

Figure 1: Urea and $\mathrm{ChCl}$ eutectic mixture in a molar ratio $2: 1$ heating for 12 hours at $90^{\circ} \mathrm{C}$.

\section{Thermodynamic analysis}

Eh-pH diagram was calculated for molality of $0.0417 \mathrm{M}$ lead, which corresponds to $0.5 \mathrm{~g}$ of lead oxide dissolved in $30 \mathrm{ml}$ eutectic mixture of urea and choline chloride in a molar ratio of 2:1, at a temperature of $90^{\circ} \mathrm{C}$.

\section{Electrochemistry experimental procedure}

The electrochemical experiments, cyclic voltammetry (CV) and chronoamperometry (CA) were carried out at a temperature of $90^{\circ} \mathrm{C}$ by using EG\&G PAR model 273A potentiostat/galvanostat. 
This instrument was controlled with a desktop computer utilizing Power Suite software from Princeton Applied Research. Cathodic current was set as positive using U.S convention. CV for the solution with dissolving lead oxide was performed using a three electrode system which consists of three platinum wires (0.004 in diameters). While solution with zinc oxide dissolving was conducted by using aluminum foil (0.04in thickness, Puratronic, $99.988 \%$, metal basis) as working electrode, platinum wire (0.004 in diameters) as counter electrode and reference electrode. The chronoamperometric electrochemical deposition experiments were performed in the same electrolyte and conducted by using copper foil ( 0.02 in thickness) as working electrode and platinum wires (0.004 in diameters) as counter and reference electrode in the lead deposition process while using aluminum foil (0.04 in thickness, Puratronic, 99.988\%, metal basis) as working electrode and platinum wires (0.004 in diameters) as counter and reference electrode in the zinc deposition process. All electrodes are rinsed by acetone and deionized water and dried before all measurements.

\section{Characterization of the deposits on the substrate}

The characterization of the lead and zinc deposits on the working electrode were analyzed by using X-ray diffraction pattern which is obtained from a Phillips MPD XRD using a monochromated $\mathrm{Cu} \mathrm{k} \alpha$ radiation. The resulting pattern was compared with the standard ICDD card. The morphology and elemental analysis of the deposits was carried out using Scanning Electron Microscope (SEM), model JEOL 7000 equipped with energy dispersive spectrometer (EDS). The SEM image was obtained by setting accelerating voltage at $20 \mathrm{kV}$, and a working distance of $10.0 \mathrm{~mm}$.

\section{Results and discussion}

Bond stretching analysis of 2:1 Urea/ChCl was carried out using Fourier Transform Infrared Spectroscopy (FTIR). When beams pass through the sample, some photons are absorbed by molecules due to their vibrational or rotational motion. Other photons pass through the molecules and send signals to the detector. The signals are received and interpreted by the detector to generate spectrum. FTIR peaks were observed at the following wavenumbers in the 2:1

Urea/ChCl sample: $3385-3180 \mathrm{~cm}^{-1} ; 1660-1640 \mathrm{~cm}^{-1} ; 1437 \mathrm{~cm}^{-1} ; 950-1190 \mathrm{~cm}^{-1}$ Figure 2 exhibits 
FTIR for 2:1 molar ratio Urea/ $\mathrm{ChCl}$ eutectic mixture. The stretched bonds corresponding to the observed peaks are given in Table II.

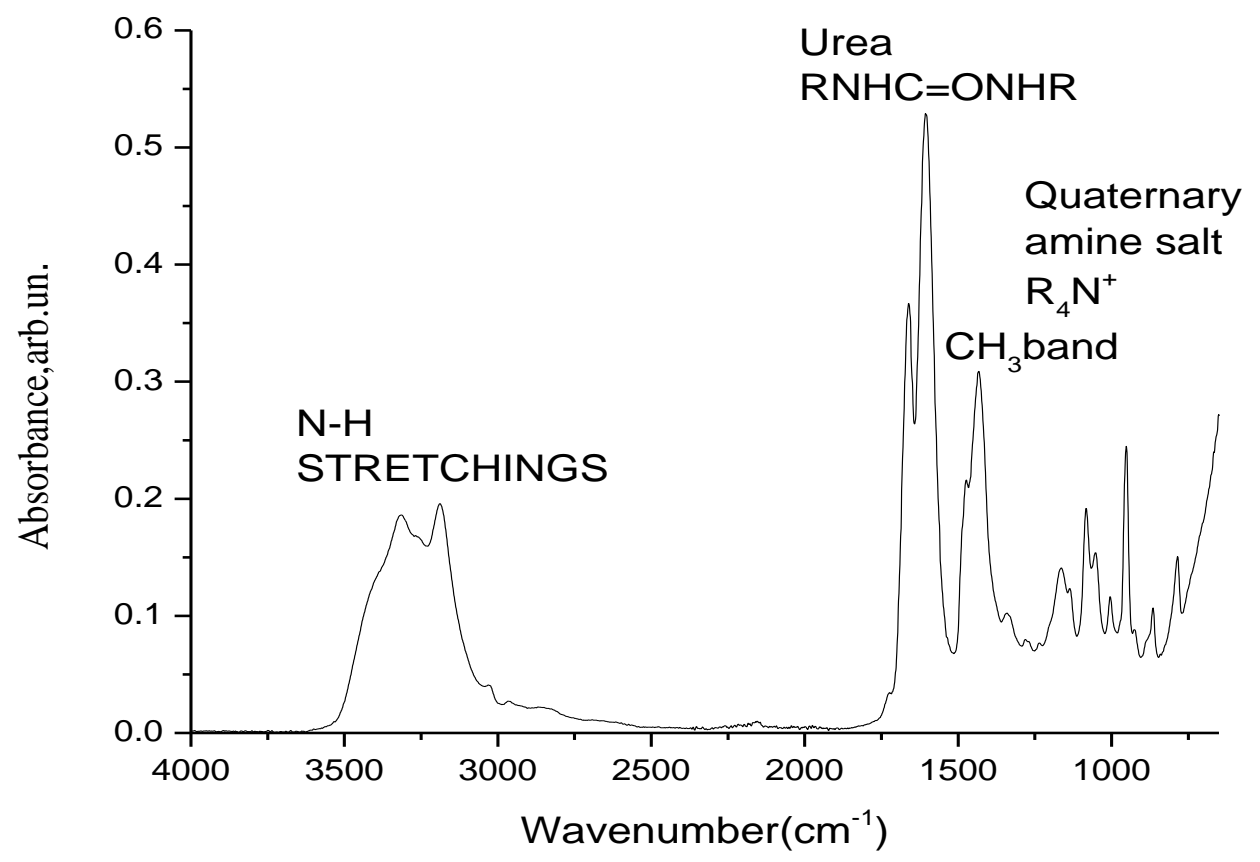

Figure 2: Infrared spectrum for 2:1 Urea/Choline Chloride mixed for 12 hours at $90^{\circ} \mathrm{C}$.

Table II. Standard infrared absorption of stretching and bond variations for different functional groups

\begin{tabular}{|l|c|l|}
\hline Functional Group & Characteristic Absorptions $\left(\mathrm{cm}^{-1}\right)$ & Intensity \\
\hline Amine N-H Stretch & $3700-3500$ & strong \\
\hline Alcohol O-H Stretch & $3550-3200$ & strong \\
\hline Amide C=O Stretch & $1690-1630$ & strong \\
\hline Amine C-N & $1080-1360$ & medium \\
\hline
\end{tabular}

Different amounts of lead oxide and zinc oxide were dissolved in the 2:1 Urea/ $\mathrm{ChCl}$ eutectic mixture between the temperatures of $70-100^{\circ} \mathrm{C}$ with constant stirring. Solution containing dissolved lead and zinc oxide was compared to that before the dissolution. Figure 3a and figure $3 b$ exhibits the different pattern obtained from Fourier Transform Infrared Spectrum. The FTIR spectrum observed after the dissolution was the same before and after the dissolution of metal oxide except for one distinct peak observed within frequency range of $2100 \mathrm{~cm}^{-1}$ to $2200 \mathrm{~cm}^{-1}$. 
The Nitrile group $(\mathrm{R}-\mathrm{C} \equiv \mathrm{N})$ and functional group $\left(\mathrm{R}-\mathrm{N}^{+} \equiv \mathrm{N}\right)$ are the only possible molecular structures which is reported to be active during this frequency range [10]. The results exhibit that lead and zinc are attached to one of these functional group as seen in the Figures $3 a$ and $3 b$. Thus the FTIR spectrum confirms the dissolution of metal oxide in the eutectic mixture.

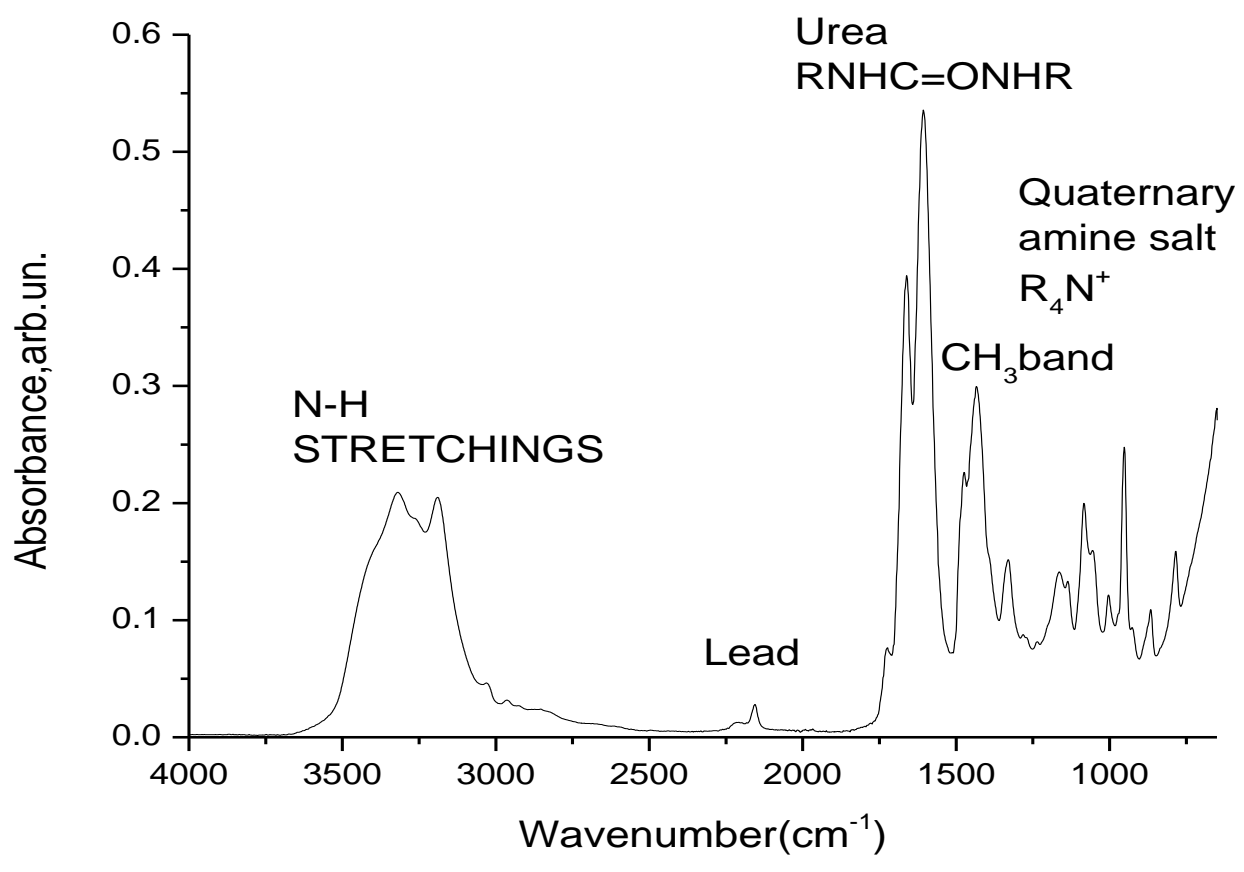

Figure 3a: Infrared spectrum with addition of lead oxide in $30 \mathrm{~mL} \mathrm{2:1} \mathrm{Urea/ChCl} \mathrm{eutectic} \mathrm{mixture}$ in a temperature of $90^{\circ} \mathrm{C}$, green line was getting from the eutectic mixture with dissolving $0.3 \mathrm{~g}$ $\mathrm{PbO}$ compared to the red line which was obtained from the 2:1 Urea and $\mathrm{ChCl}$ eutectic mixture. 


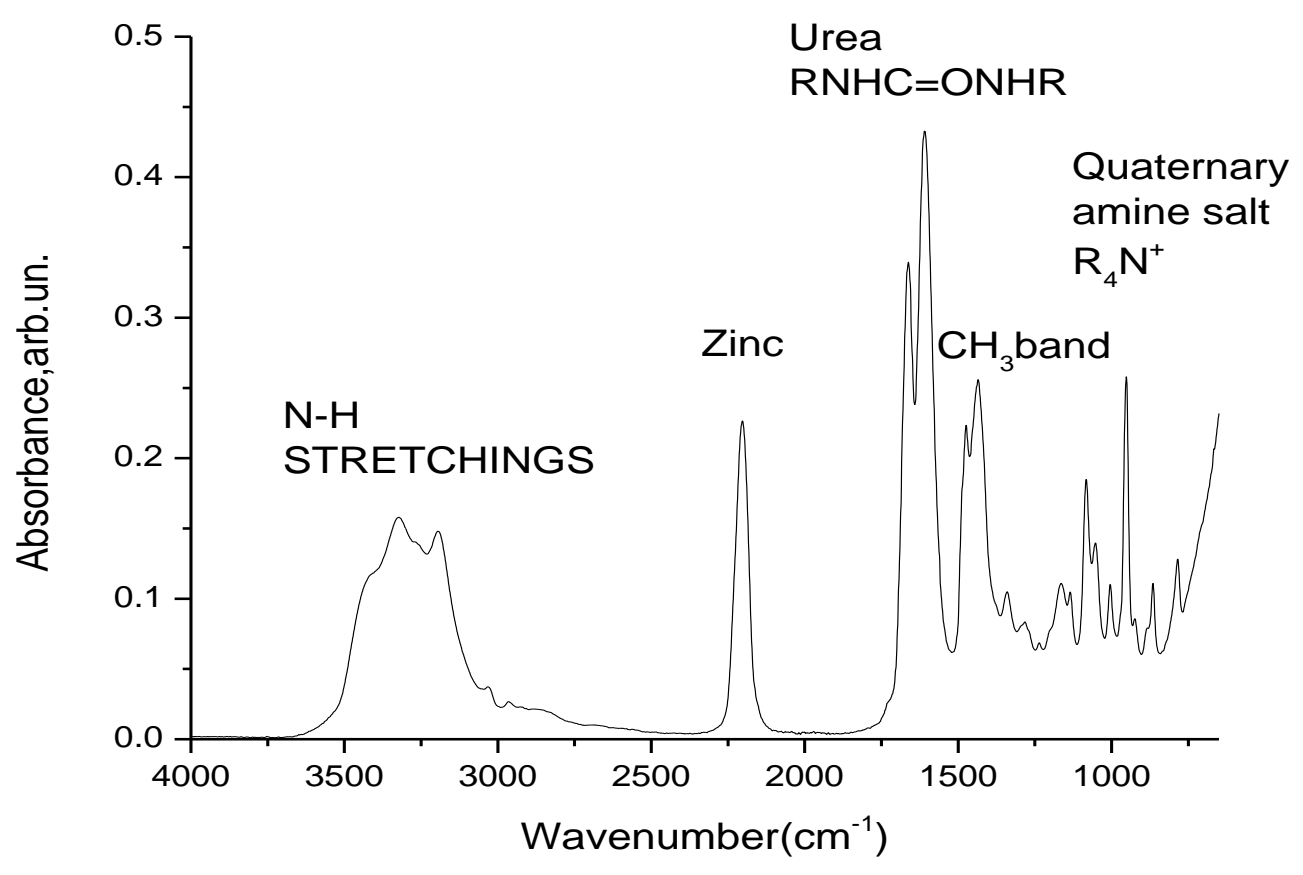

Figure 3b: Infrared spectrum with addition of zinc oxide in $30 \mathrm{~mL}$ 2:1 Urea/ChCl eutectic mixture in a temperature of $90^{\circ} \mathrm{C}$

It is proposed that the intensity of the peak for metal increased with increasing amount metal oxide being dissolving. To find the suitable condition for dissolving metal oxide in the eutectic mixture, the variation of absorbance of dissolved metal oxide in the $2: 1 \mathrm{Urea} / \mathrm{ChCl}$ eutectic mixture for (I) time, (II) amount, (III) temperature as parameters was studied in the solution with dissolving lead oxide. Figure 4 shows the time effect by collecting data of absorbance peak height value from infrared spectrum. The dissolution process mostly occurred during the first two hours. The change in the absorbance peak height is relatively small after 20 hours. Figure 5 shows the effect of amount of $\mathrm{PbO}$ by collecting data of absorbance peak height value from infrared spectrum. It is seen that the peak value reaches a maximum when adding $0.5 \mathrm{~g}$ lead oxide in the solution at $90^{\circ} \mathrm{C}$ for 20 hours dissolution. A clear transparent solution was obtained when the amount of $\mathrm{PbO}$ was $0.5 \mathrm{~g}$ or less. An increase in the amount of $\mathrm{PbO}$ above $0.5 \mathrm{~g}$ results in a turbid solution with a decrease in the corresponding absorbance peak height. Figure 6 shows the temperature effect by collecting data from peak height value in the infrared spectrum. It can be seen that the absorbance peak value reach its maximum point at $90^{\circ} \mathrm{C}$. The absorbance was 
relatively less at lower temperatures, while the effect of increase in temperature above $90^{\circ} \mathrm{C}$ was not noticeable.

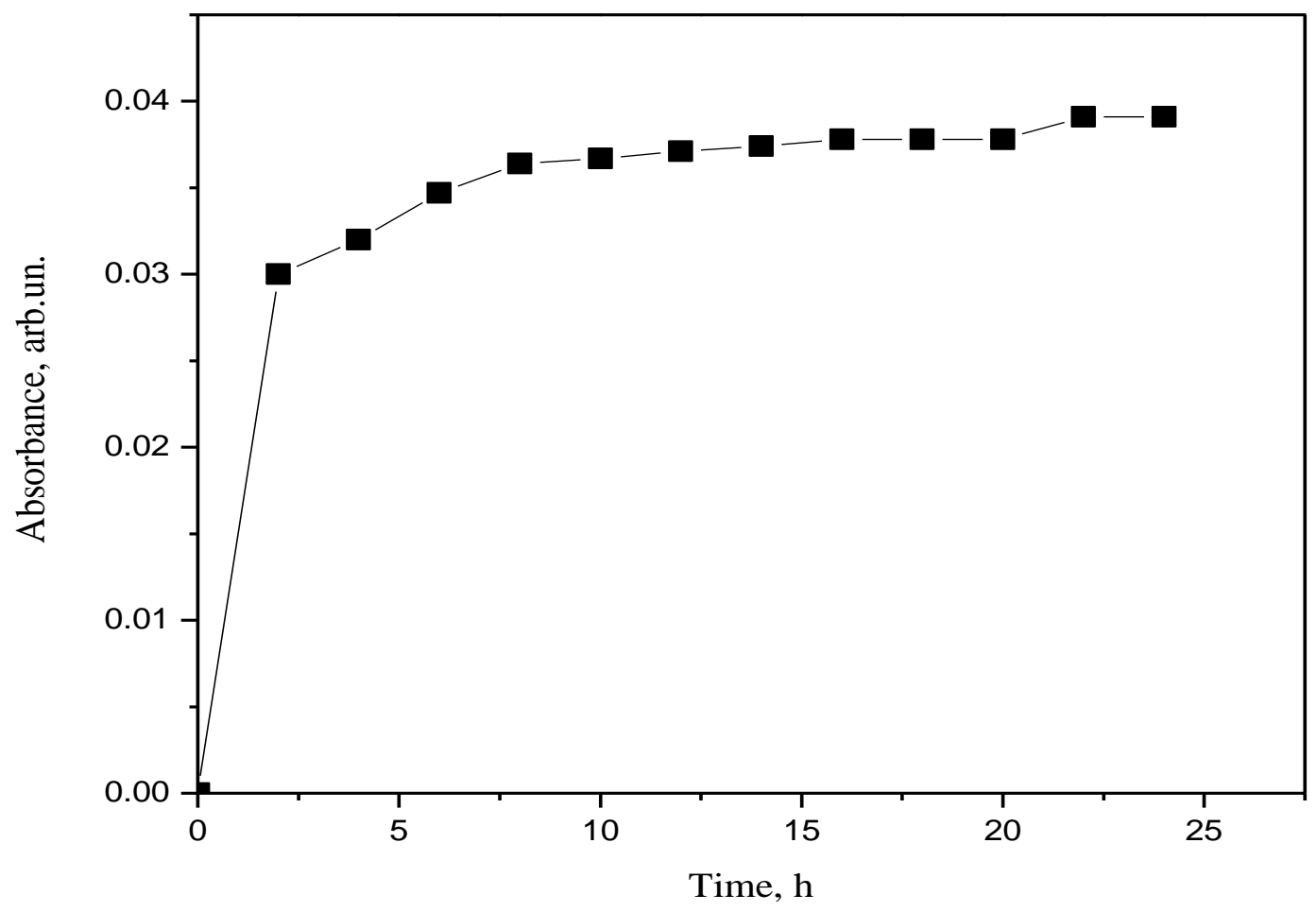

Figure 4: Effect of dissolution time on the amount of $\mathrm{PbO}$ dissolved in 30mL 2:1 molar ratio of Urea and $\mathrm{ChCl}$ eutectic mixture using $0.5 \mathrm{~g}$ lead oxide mixing for 24 hours in a temperature of $90^{\circ} \mathrm{C}$ 


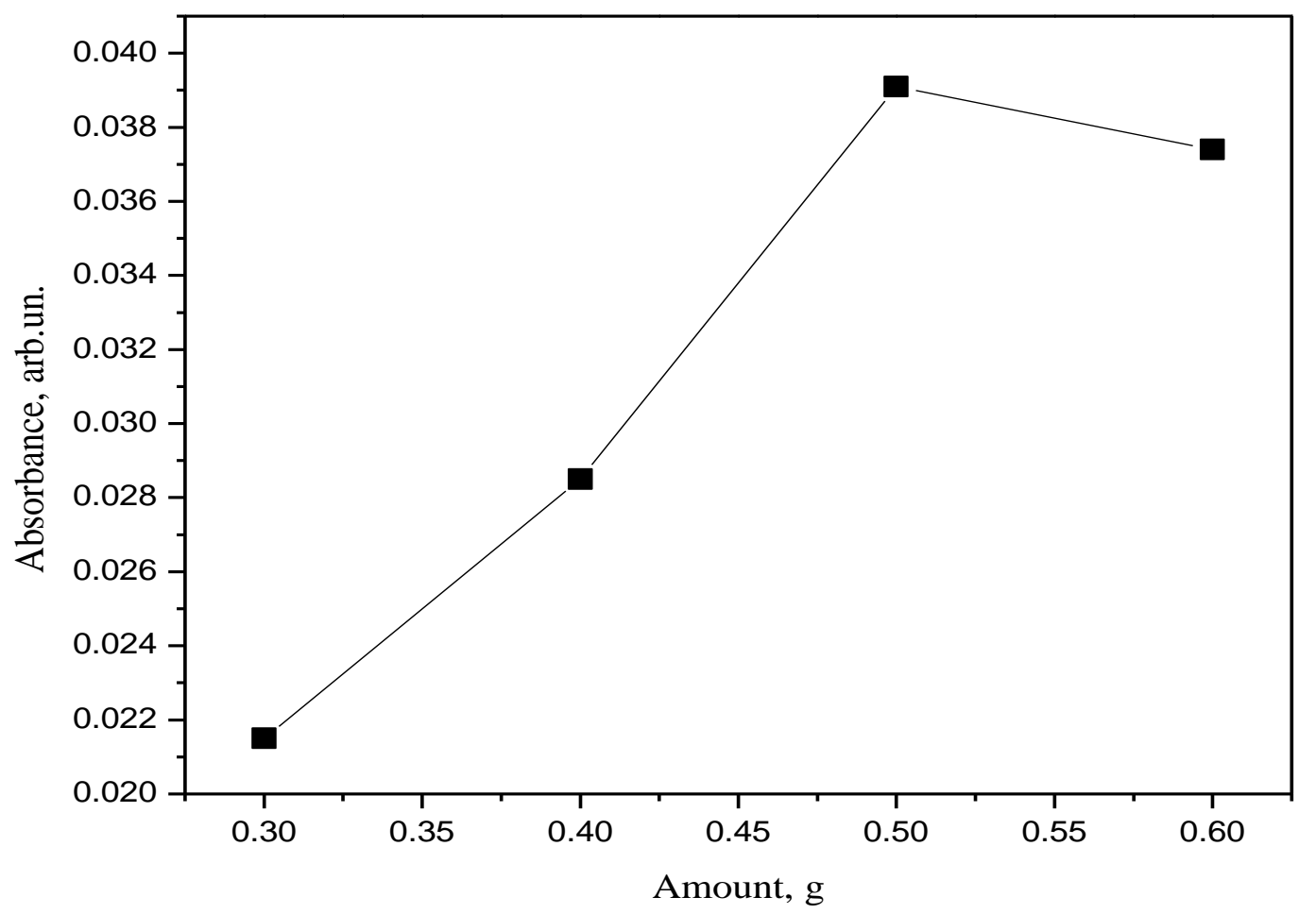

Figure 5: Effect of amount of lead oxide addition on its dissolution in 30mL 2:1 molar ratio of Urea and $\mathrm{ChCl}$ ionic liquid for 20 hours in a temperature of $90^{\circ} \mathrm{C}$ 


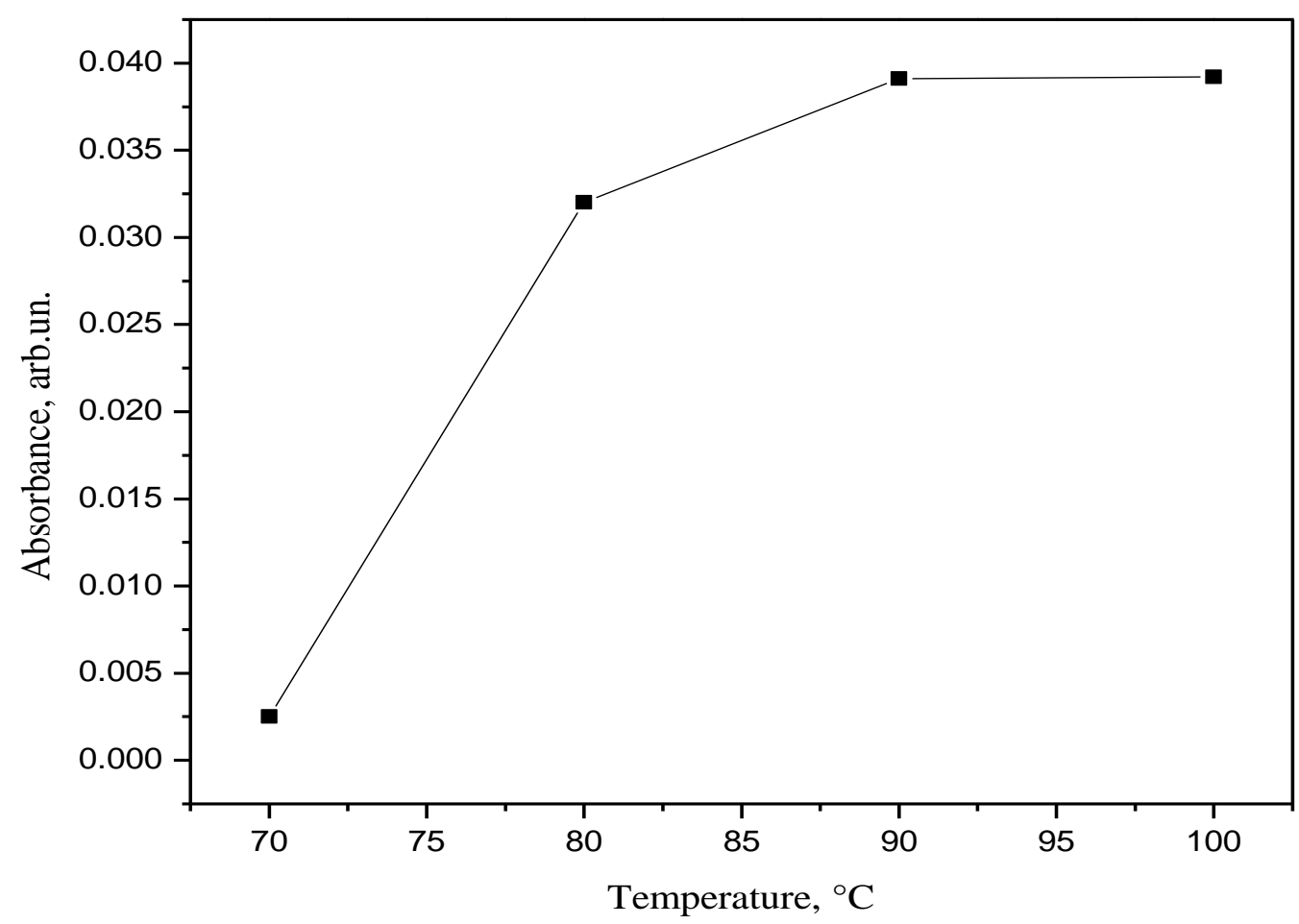

Figure 6: Effect of temperature on the dissolution of $0.5 \mathrm{~g}$ lead oxide in $30 \mathrm{~mL} 2: 1$ molar ratio of Urea and $\mathrm{ChCl}$ ionic liquid for 20 hours

The effect of redox potential (Eh) and the $\mathrm{pH}$ diagram is summarized in Figure 7. Important thermodynamic data was used in this experiment in order to predict the species in the given experimental condition. The Eh-pH diagram was calculated for molality of $0.0417 \mathrm{~mol} / \mathrm{kg}$ lead, which corresponds to $0.3 \mathrm{~g}$ of $\mathrm{PbO}$ dissolved in $30 \mathrm{~mL}$ eutectic mixture, at a temperature of $90^{\circ} \mathrm{C}$. As seen in figure 7 , at any potential below $-0.35 \mathrm{~V}$ with a $\mathrm{pH}$ ranging from 0 to 6 , elemental lead is predicted to be the dominant species present in the solution. With the increase in the $\mathrm{pH}$ above 6 , the stability of $\mathrm{Pb}$ decreases to slightly lower potentials. The reduction potentials used for the electro-deposition of $\mathrm{Pb}$ vary between $-0.6 \mathrm{~V}$ and $-1.9 \mathrm{~V}$. The acidic $\mathrm{pH}$ of the $\mathrm{Pb}$ dissolved ionic liquid and the working reduction potentials mentioned above confirm that lead will be the only stable phase. 


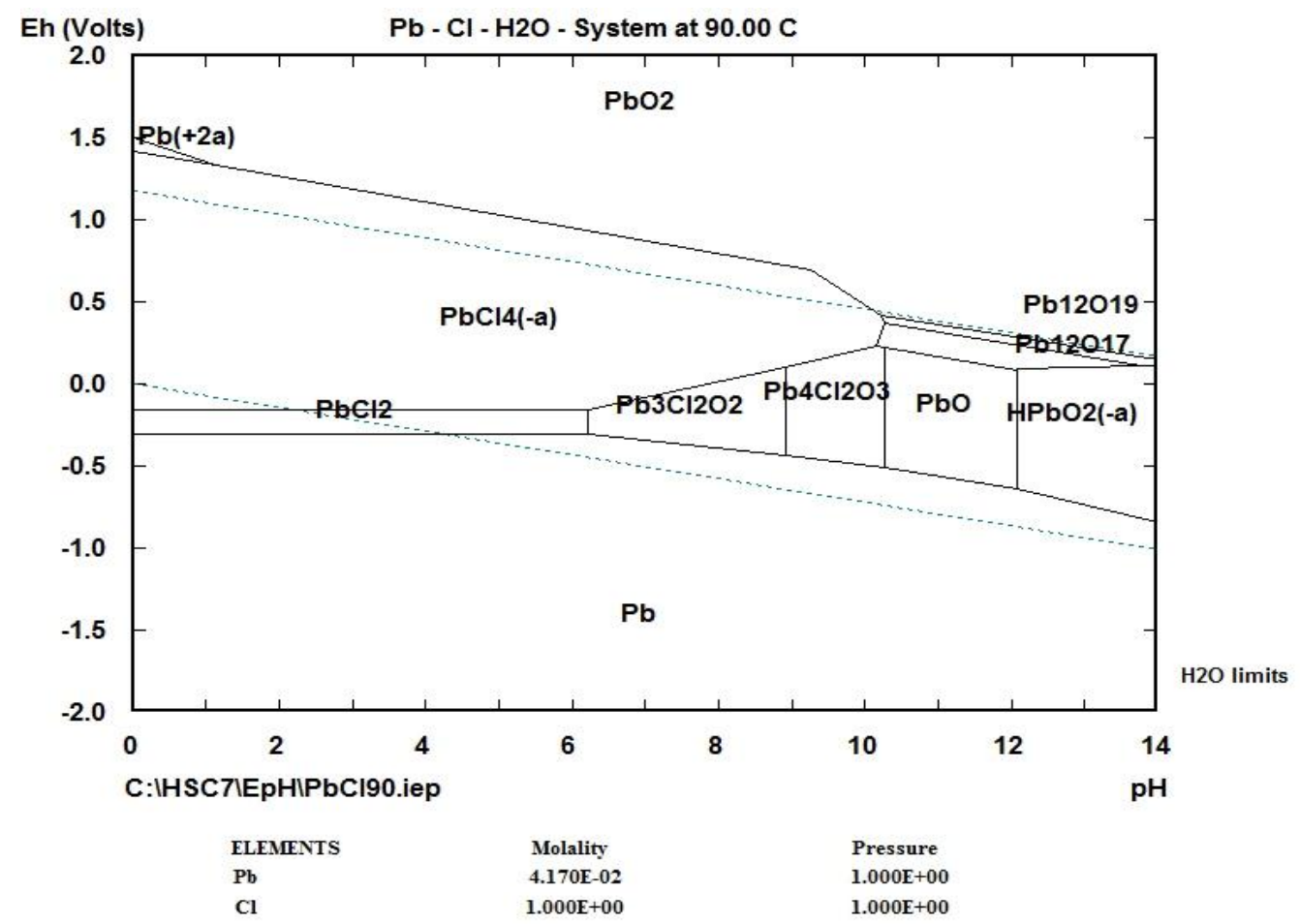

Figure 7: Eh-pH diagram for morality $0.0417 \mathrm{~mol} / \mathrm{kg}$ lead in $30 \mathrm{~mL} 2: 1$ molar ratio of Urea and $\mathrm{ChCl}$ eutectic mixture (at $\left.90^{\circ} \mathrm{C}, 1 \mathrm{~atm}\right)$

Voltammograms were used to study the deposition mechanisms and to find the best deposition potential range. The $\mathrm{CV}$ obtained for a solution with dissolved metal oxide is shown in Figures 8(a) and 8(b) for lead oxide and in Figure 8(c) for zinc oxide. In figure 8a, one major reduction (labeled C) wave and two minor reduction waves (labeled as A and B) are observed during cathodic scan with $\mathrm{E}_{\mathrm{C}}^{\mathrm{o}}=-1.6 \mathrm{~V}, \mathrm{E}_{\mathrm{A}}^{\mathrm{o}}=-1.0 \mathrm{~V}, \mathrm{E}^{\mathrm{o}}{ }_{\mathrm{B}}=-0.6 \mathrm{~V}$. Two corresponding oxidation peaks were observed during anodic scan with $\mathrm{E}_{1}^{\mathrm{o}}=+0.25 \mathrm{~V}, \mathrm{E}_{2}^{\mathrm{o}}=+0.5 \mathrm{~V}$. The three different lead containing species in the urea based ionic liquid need to be determined by FAB mass spectra in the future work. Although platinum wire has been used to determine reduction potential in reduction of lead oxide, its high cost limits its use as a common working electrode. However, the

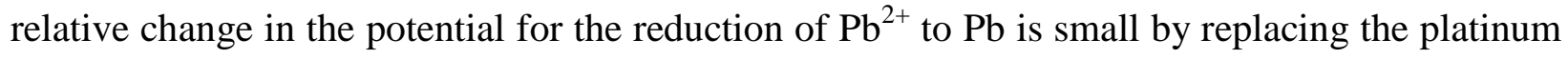
wire for a different working electrode. Copper electrode has been chosen due to its high electrical conductivity and good performance in surface absorption. Figure $8 \mathrm{~b}$ confirmed the assumption that replacing working electrode does not affect potential for reducing the metal. 
There is only one reduction wave labeled as E observed during Cathodic scan with $\mathrm{E}^{\mathrm{o}}, \mathrm{C}_{\mathrm{C}}=-1.3 \mathrm{~V}$ and one oxidation wave labeled as $\mathrm{F}$ observed during anodic scan with $\mathrm{E}_{\mathrm{A}}^{\mathrm{o}}=-0.75 \mathrm{~V}$ in the $\mathrm{CV}$ for zinc oxide as shown in Figure 8(c). This can be explained by the fact that the only zinc containing species is $\mathrm{ZnCl}_{3}{ }^{-}$in the urea based ionic liquid [11]. The reduction of $\mathrm{ZnCl}_{3}{ }^{-}$to $\mathrm{Zn}$ is the only reaction in the solution. To eliminate the influence of fast scan rate on the $\mathrm{CV}$ for $\mathrm{Zn}$ reduction, a slower scan rate which is equal to $5 \mathrm{mv} / \mathrm{s}$ was exhibited comparable to the faster scan rate which is equal to $50 \mathrm{mv} / \mathrm{s}$, as seen in figure $8 \mathrm{c}$. The result demonstrates that scan rate only has impact on the scale of the reduction peak not shift the reduction potential. Theoretically, Nernst Equation was being used to determine the reduction potential of $\mathrm{Pb}^{2+}$ to $\mathrm{Pb}$ and $\mathrm{Zn}^{2+}$ to $\mathrm{Zn}$. The standard potential for reducing $\mathrm{Pb}^{2+}$ to $\mathrm{Pb}$ is $-0.13 \mathrm{~V}$ (vs. SHE) and for reducing $\mathrm{Zn}^{2+}$ to $\mathrm{Zn}$ is $-0.76 \mathrm{~V}$ (vs. SHE). The chemical reaction is listed below:

$$
\begin{aligned}
& \mathrm{Pb}^{2+}+2 \mathrm{e}^{--->} \mathrm{Pb}^{0} ; \mathrm{E}^{\mathrm{o}}=-0.13 \mathrm{~V} \text { (vs. SHE) } \\
& \mathrm{Zn}^{2+}+2 \mathrm{e}^{--->} \mathrm{Zn}^{0} ; \mathrm{E}^{\mathrm{o}}=-0.76 \mathrm{~V} \text { (vs. SHE) }
\end{aligned}
$$

Using Nernst Equation, the potentials obtained under current experimental condition were $\mathrm{E}^{\mathrm{o}}=$ $0.1315 \mathrm{~V}$ and $-0.7613 \mathrm{~V}$ corresponding to the reduction of $\mathrm{Pb}$ and $\mathrm{Zn}$, respectively. Converting the reference electrode from hydrogen to platinum which is currently being used, the theoretical reduction potential has been determined to be $\mathrm{E}^{\mathrm{o}}=-1.33 \mathrm{~V}$ and $\mathrm{E}^{\mathrm{o}}=-1.96 \mathrm{~V}$ for $\mathrm{Pb}$ and $\mathrm{Zn}$, respectively. Thus, the major reduction potential $\mathrm{C}$ which is equal to $-1.6 \mathrm{~V}$ (figure $8 \mathrm{a}$ ) have been confirmed for the reduction of $\mathrm{Pb}^{2+}$ to $\mathrm{Pb}$ and potential $\mathrm{E}$ which is equal to $-1.3 \mathrm{~V}$ (figure $8 \mathrm{c}$ ) for the reduction of $\mathrm{Zn}^{2+}$ to $\mathrm{Zn}$ in the above-mentioned experimental conditions. 


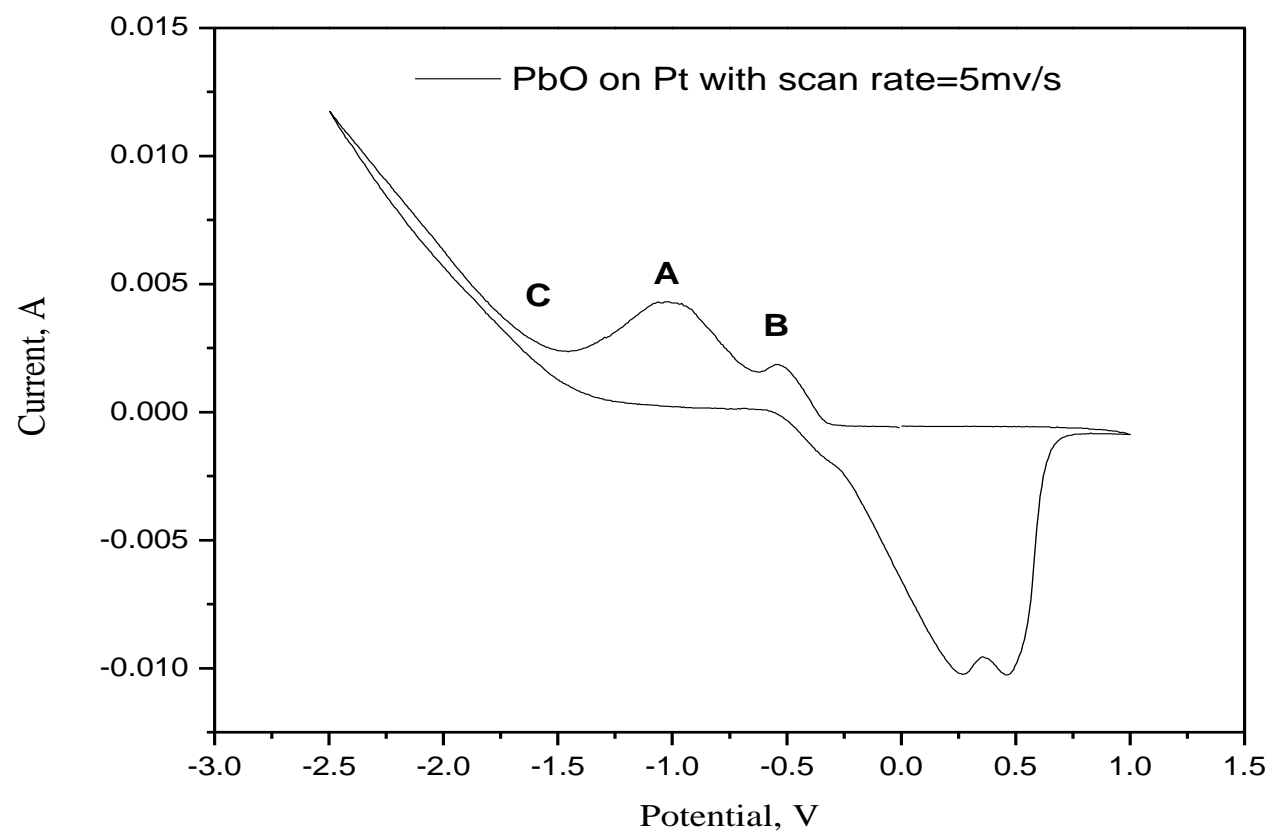

Figure 8a: $\mathrm{CV}$ of $0.3 \mathrm{~g} \mathrm{PbO}$ in 30mL 2:1 molar ratio of Urea and $\mathrm{ChCl}$ by using $\mathrm{Pt}$ working electrode in a temperature of $90^{\circ} \mathrm{C}$, scan rate at $5 \mathrm{mv} / \mathrm{s}$ 


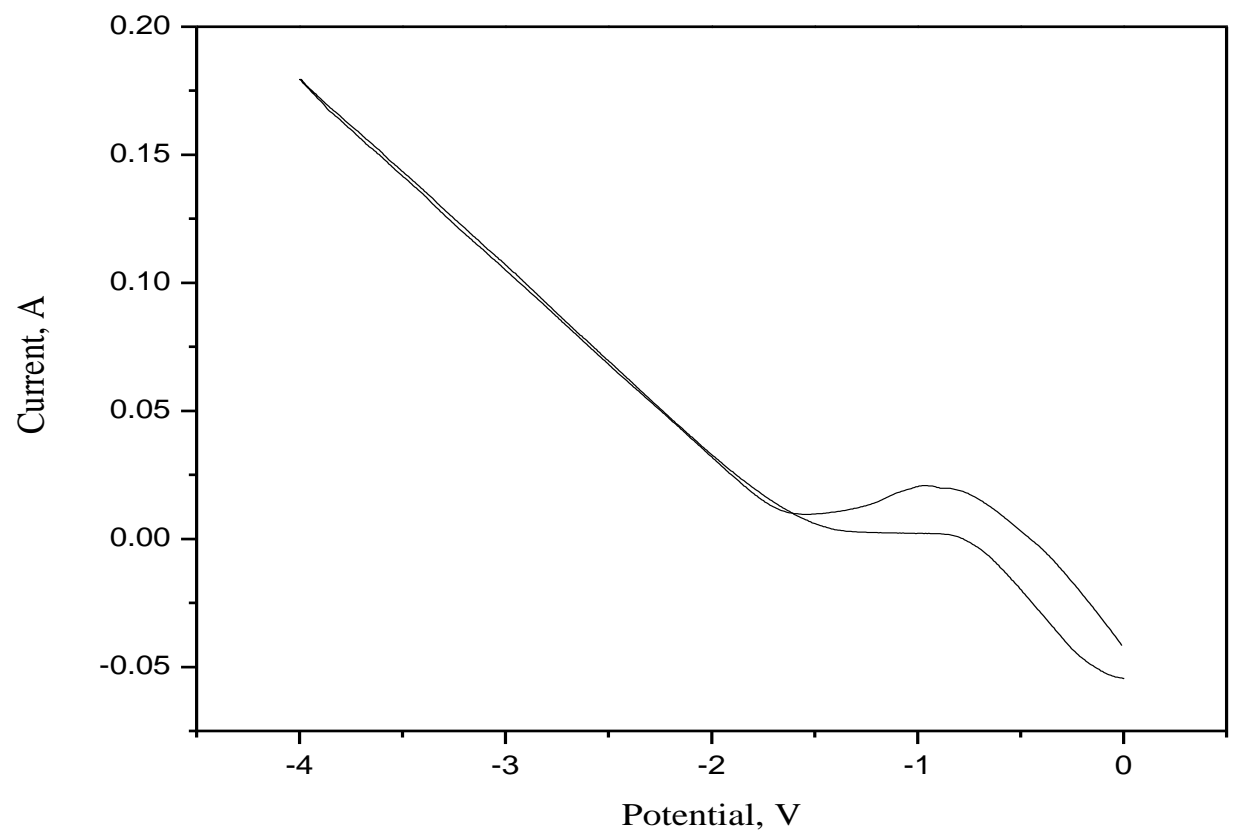

Figure 8b: Cyclic voltammetry of $0.3 \mathrm{~g} \mathrm{PbO}$ in $30 \mathrm{~mL} 2: 1$ molar ratio of Urea and $\mathrm{ChCl}$ in non-stirring solution by using $\mathrm{Cu}$ working electrode in a temperature of $90{ }^{\circ} \mathrm{C}$ 


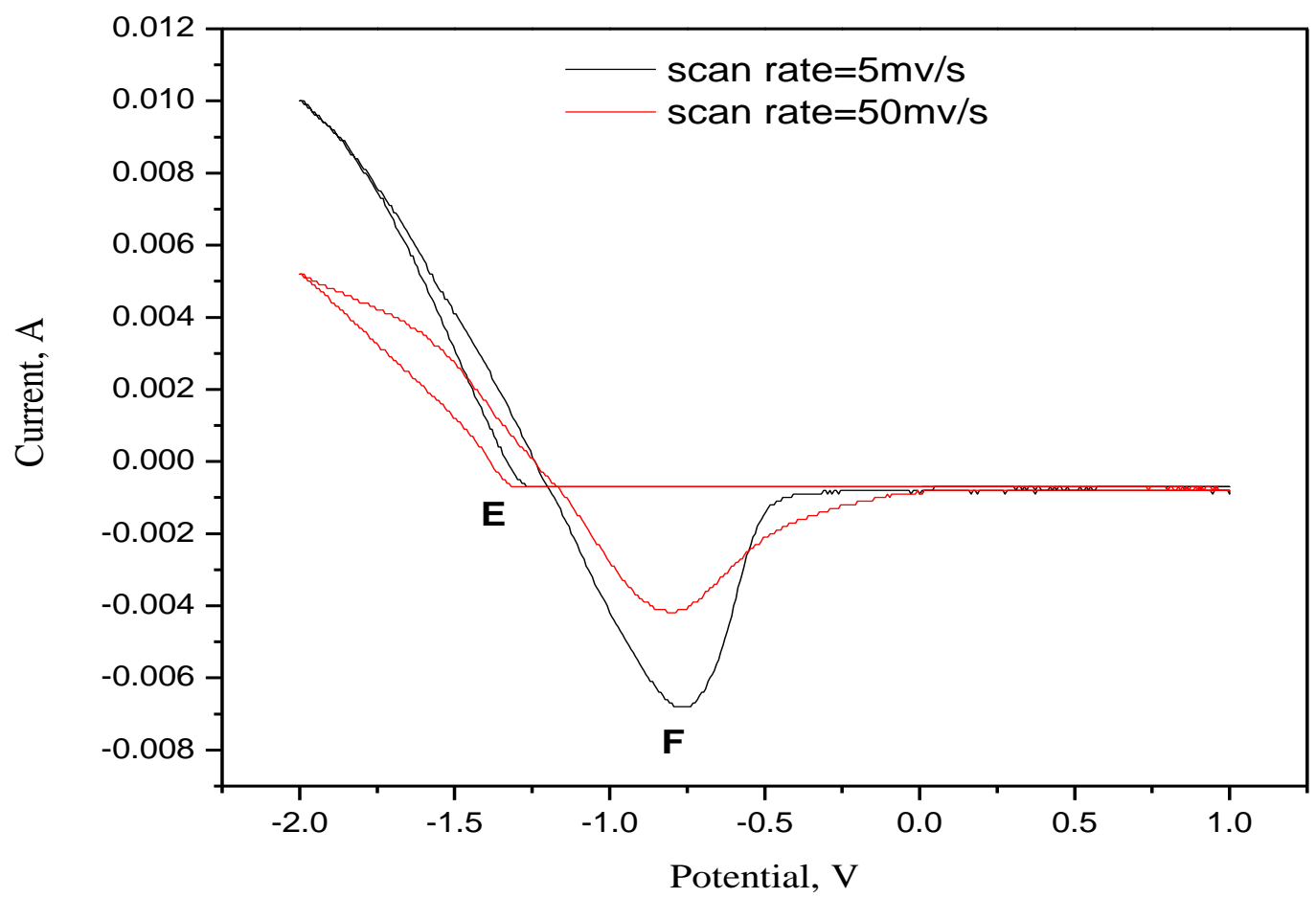

Figure 8c: Cyclic voltammetry of $2.0 \mathrm{~g}$ Zinc oxide in $30 \mathrm{~mL} 2: 1$ molar ratio of Urea and $\mathrm{ChCl}$ in non-stirring solution by using aluminum working electrode in a temperature of $90^{\circ} \mathrm{C}$, scan rate is $5 \mathrm{mv} / \mathrm{s}$ and $50 \mathrm{mv} / \mathrm{s}$ respectively

The cyclic voltammetry of $\mathrm{PbO}$ dissolved in the eutectic mixture shows that the reduction of $\mathrm{PbO}$ occurs at potentials less than or equal to $-1.6 \mathrm{~V}$. This leads to the design of the following set of experiments shown in Table III for electro-deposition of lead.

Table III: Experimental conditions for the electro-deposition of $\mathrm{Pb}$ from $\mathrm{PbO}$

\begin{tabular}{|c|c|c|c|c|c|c|}
\hline $\begin{array}{c}\text { Experimental } \\
\text { Number }\end{array}$ & $\begin{array}{c}\text { Temperature } \\
\left({ }^{\circ} \mathrm{C}\right)\end{array}$ & $\begin{array}{l}\mathbf{E}_{\text {red }}^{\mathbf{o}} \\
(\mathbf{V})\end{array}$ & $\begin{array}{c}\text { Time } \\
\text { (h) }\end{array}$ & $\begin{array}{c}\text { Stirring } \\
(\mathbf{Y} / \mathbf{N})\end{array}$ & Cathode & $\begin{array}{c}\text { Amount of } \\
\mathrm{PbO}(\mathrm{g})\end{array}$ \\
\hline 1 & 90 & $\begin{array}{c}-1.8 \\
\end{array}$ & 6 & $\mathrm{~N}$ & $\overline{\mathrm{Cu}}$ & 0.3 \\
\hline 2 & 90 & -2.0 & 1 & $Y$ & $\mathrm{Cu}$ & 0.3 \\
\hline 3 & 90 & -1.8 & 1 & $Y$ & $\mathrm{Cu}$ & 0.3 \\
\hline 4 & 90 & -2.0 & 0.5 & $Y$ & $\mathrm{Cu}$ & 0.3 \\
\hline 5 & 90 & -1.8 & 0.5 & $\mathrm{Y}$ & $\mathrm{Cu}$ & 0.3 \\
\hline
\end{tabular}


The chronoamperometry experiments were carried out for lead oxide in $2: 1 \mathrm{Urea} / \mathrm{ChCl}$ eutectic mixture at $\mathrm{E}_{1}^{\mathrm{o}}=-1.8 \mathrm{~V}, \mathrm{E}^{\mathrm{o}}{ }_{2}=-2.0 \mathrm{~V}$ using copper foil as working electrode at $90^{\circ} \mathrm{C}$ and for zinc oxide in same electrolytes at fixed potential $\mathrm{E}^{\mathrm{O}}=-1.9 \mathrm{~V}$ using aluminum foil as working electrode for 4 hours at a temperature of $90^{\circ} \mathrm{C}$. Figure $9 \mathrm{a}$ and $9 \mathrm{~b}$ show current density as a function of time at fixed potential: $\mathrm{E}_{1}^{\mathrm{o}}=-1.8 \mathrm{~V}$ kept for six hours in a non-stirring solution for lead deposition and $E^{0}=-1.9 \mathrm{~V}$ kept for four hours in a non-stirring solution for zinc deposition. The change in electric current with respect to time in a controlled potential experiment is described by Cottrell equation:

$$
i=\frac{n F A c_{j}^{0} \sqrt{D_{j}}}{\sqrt{\pi t}}
$$

Where: $C_{j}{ }^{0}$ is initial concentration of the reducible analyte in $\mathrm{mol} / \mathrm{cm}^{2} ; D_{j}$ is diffusion coefficient for species in $\mathrm{cm}^{2} / \mathrm{s} ; n$ is the number of electrons; $A$ is the area of the (planar) electrode in $\mathrm{cm}^{2} ; F$ is Faraday constant which is equal to $96485 \mathrm{C} / \mathrm{mol} ; i$ is Faradaic current; $t$ is time

Current decreases during electro-deposition due to the depletion of the reducible analyte in the solution. Reasons for the current vs. time plot differing from Cottrell equation are twofold. First, the capacitive current decreases with decreasing Faradaic current. According to the equation for capacitive current as a function of time: $i=e^{-k t}$, the capacitive current decreases more rapidly than Faradaic current. Thus, at longer time the ratio of Faradaic current to the capacitive current is larger. Second, based on the observation in the cyclic voltammetry diagram, there are more than one chemical reactions happening in the system. Hence, the above mentioned two reasons may be contributing to the deviation of the experimental current vs. time plot to that of the Cottrell equation.

These plots for the deposition process were used to determine the theoretical weight gain. It was done using Faraday's law which is given by, $\mathrm{W}_{\mathrm{t}}=\mathrm{Ita} / \mathrm{nF}$, where: $\mathrm{W}_{\mathrm{t}}=$ Theoretical weight that will be deposited for the amount of charge passed; $I=$ current, $A ; t=$ time, $\mathrm{s} ; \mathrm{a}=$ atomic weight of $\mathrm{Pb}=207.2 \mathrm{~g} / \mathrm{mol} ; \mathrm{n}=$ number of electron transfer $=2 ; \mathrm{F}=$ Faraday's constant $=96500$ C/equivalent. The product $(\mathrm{I} \cdot \mathrm{t})$ is obtained from the area under the current vs. time graph. Area under the curve $=\mathrm{It}=207.95$ A.s; $\mathrm{W}_{\mathrm{t}}=0.2229 \mathrm{~g}$; Experimental weight: $\Delta \mathrm{W}=0.1932 \mathrm{~g}$. 
$\eta=$ actual weight $(\Delta \mathrm{W}) /$ Theoretical weight $\left(\mathrm{W}_{\mathrm{t}}\right)=86.67 \%$.

The corresponding result for Zinc in figure $9 \mathrm{~b}$ which conducted for $2.0 \mathrm{~g} \mathrm{ZnO}$ dissolved in the $30 \mathrm{~mL} \mathrm{2:1} \mathrm{molar} \mathrm{ratio} \mathrm{Urea} \mathrm{and} \mathrm{ChCl}$ eutectic mixture electrolyzing for 4 hours is listed below:

$\mathrm{W}_{\mathrm{T}}=\mathrm{Ita} / \mathrm{nF}=0.34 \mathrm{~g} ; \Delta \mathrm{W}=0.3252 \mathrm{~g}$

$\eta=$ actual weight $(\Delta \mathrm{W}) /$ Theoretical weight $\left(\mathrm{W}_{\mathrm{t}}\right)=95.67 \%$

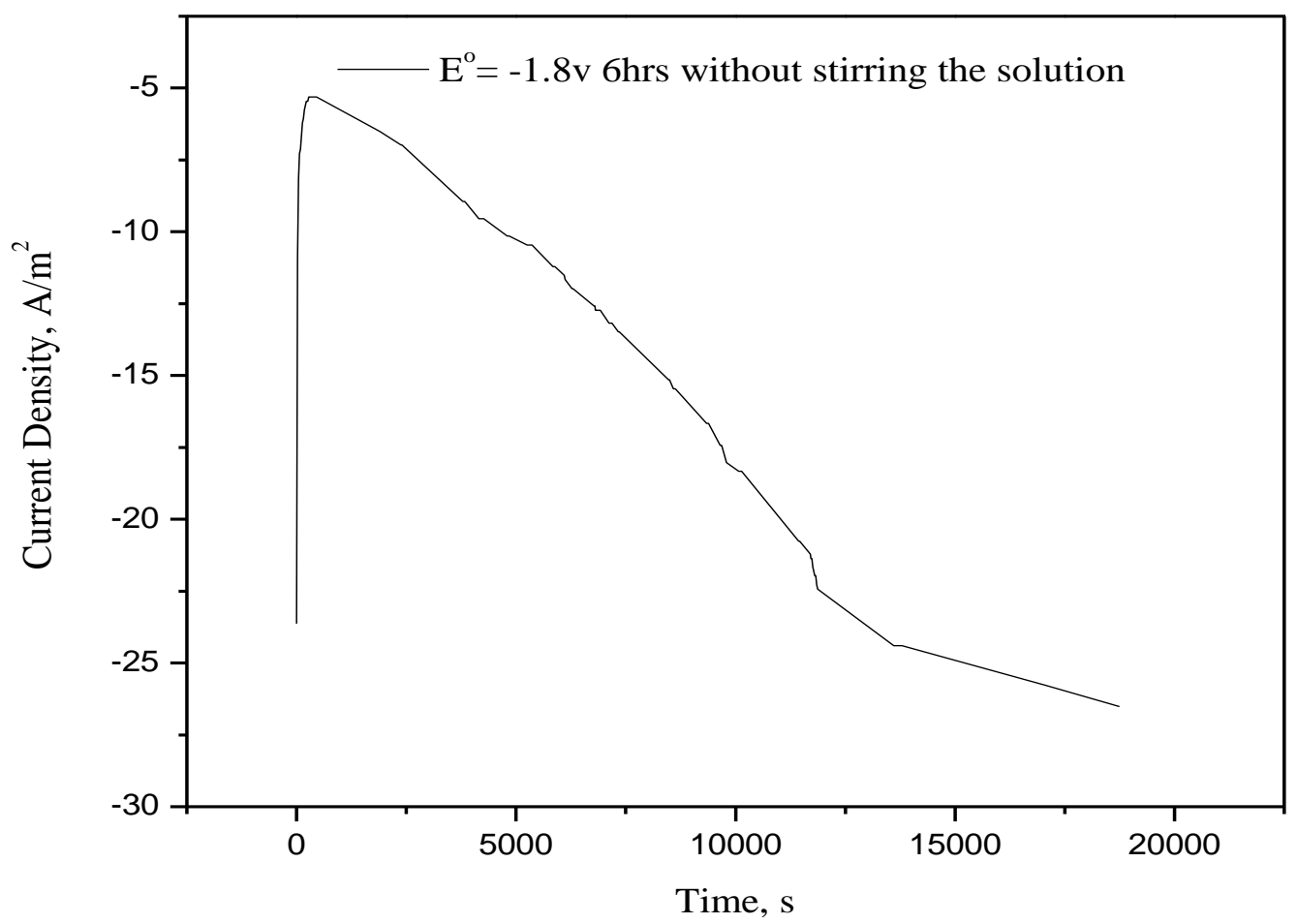

Figure 9a: Electro-deposition of $0.3 \mathrm{~g} \mathrm{PbO}$ in $30 \mathrm{~mL} 2: 1$ molar ratio of Urea and $\mathrm{ChCl}$ eutectic mixture on $\mathrm{Cu}$ electrode at fixed potential $\mathrm{e}=-1.8 \mathrm{~V}$ in non-stirring solution for six hours 


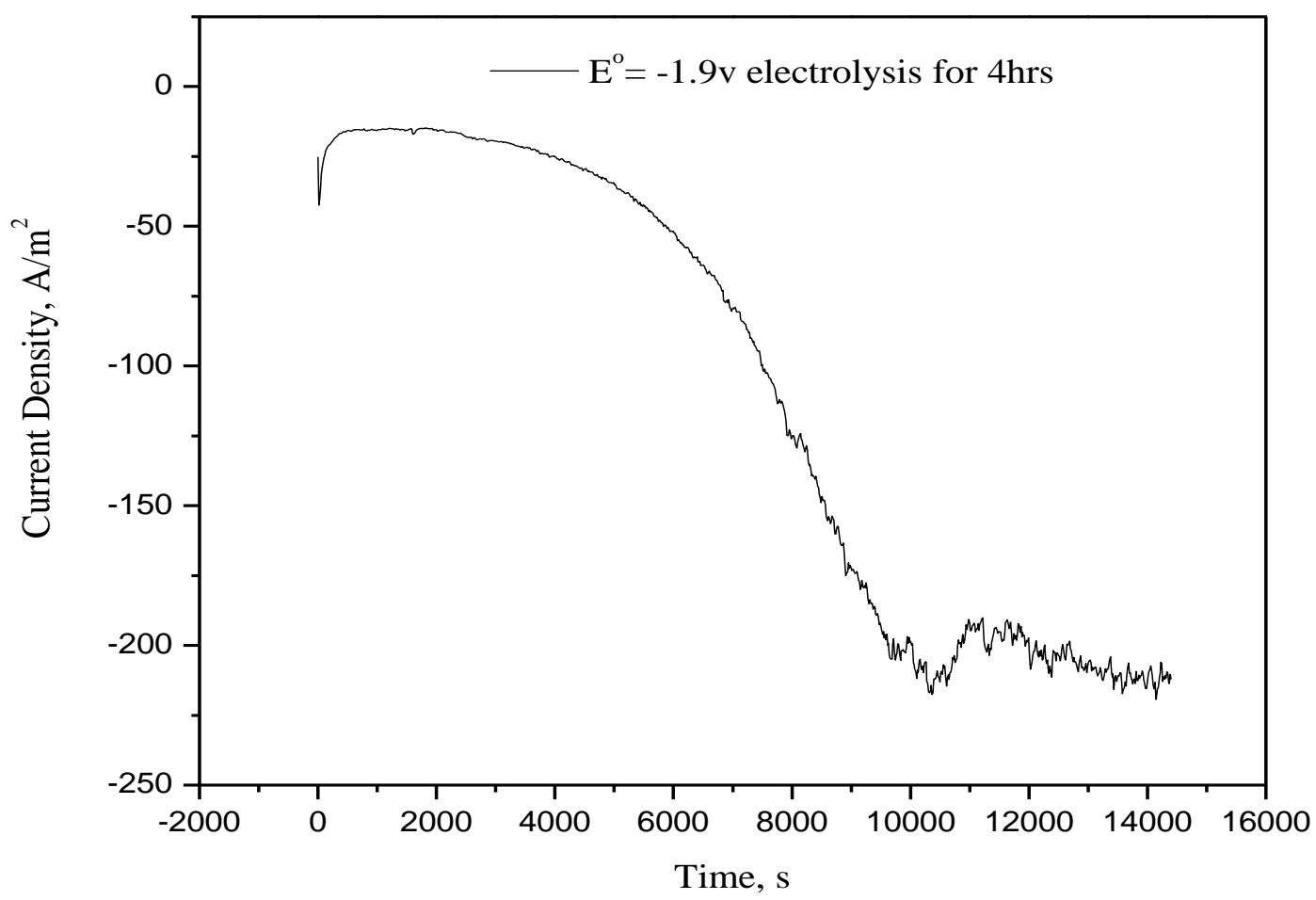

Figure 9b: Electro-deposition of $2.0 \mathrm{~g}$ zinc oxide in $30 \mathrm{~mL} \mathrm{2:1} \mathrm{molar} \mathrm{ratio} \mathrm{of} \mathrm{Urea} \mathrm{and}$ $\mathrm{ChCl}$ eutectic mixture on $\mathrm{Al}$ electrode at fixed potential of $-1.9 \mathrm{~V}$ in non-stirring solution for four hours

Figure 10 shows the effect of stirring the solution during the electro-deposition process for a fixed reduction potential of $\mathrm{E}^{\mathrm{o}}=-2.0 \mathrm{~V}$ and at two different times, namely, 0.5 hour and 1 hour. A comparison with the results from the experiment with no stirring, it is seen that stirring leads to a lower current efficiency and higher energy consumption. On the other hand, complete reduction of the metal oxide to metal was accomplished in about an hour using stirring compared to 6 hours in the case of no stirring. A comparison of the results with stirring the solution shows that the current efficiency and the energy consumption values are comparable in all the four experiments, as seen in Table V. It is found that an increase in the reduction potential changes the current efficiency by about $\pm 4 \%$ which is almost negligible. Similar observation can be made on the energy consumption of the reaction. Hence it can be concluded that stirring the solution increases the rate of the reduction reaction by increasing the migration of $\mathrm{Pb}$ ions from the bulk solution to the electrode-electrolyte interface. 


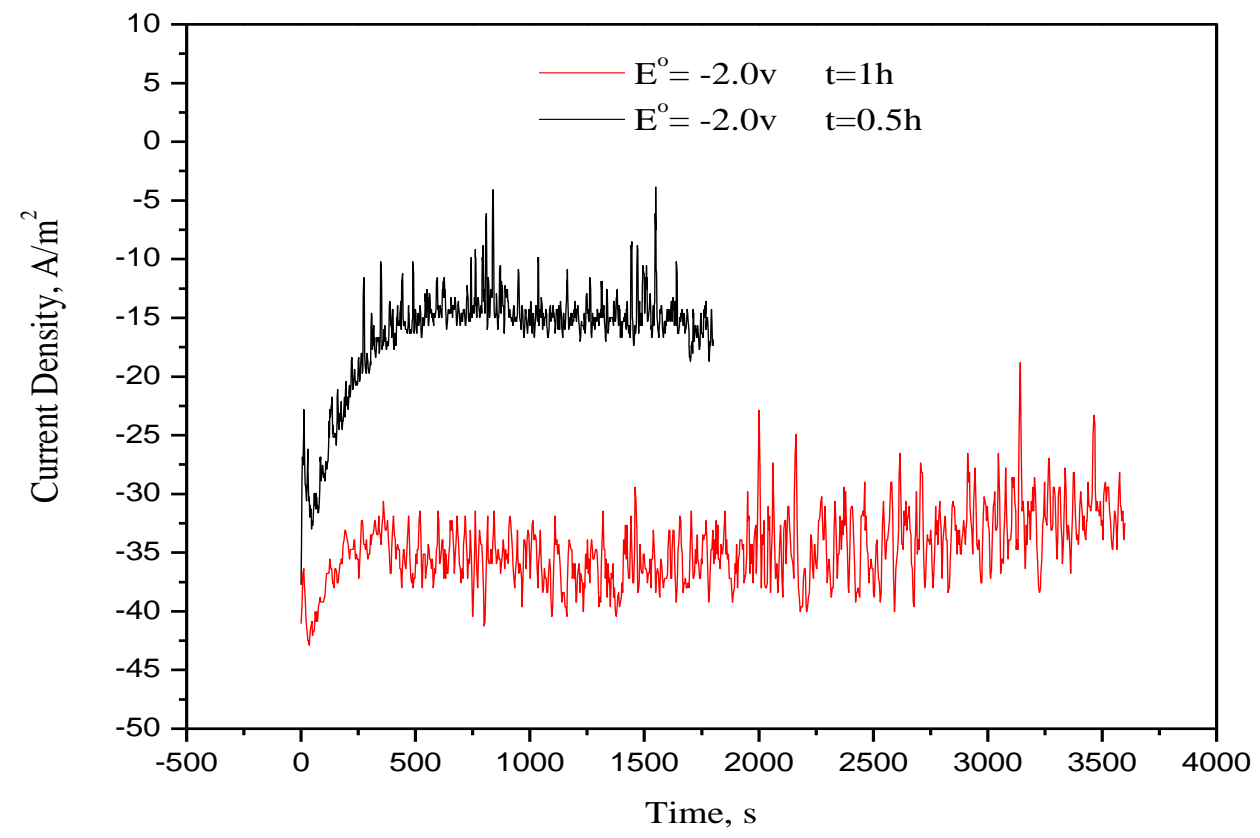

Figure 10: Electro-deposition of $0.3 \mathrm{~g}$ PbO in 30mL 2:1 molar ratio of Urea and $\mathrm{ChCl}$ eutectic mixture on $\mathrm{Cu}$ electrode at fixed potential $\mathrm{E}^{\mathrm{o}}=-2.0 \mathrm{~V}$ in a solution with constant stirring rate for 0.5 hour and 1 hour

The comparison of change in parameters (potential, temperature, and amount) for zinc deposition experiment maintaining other parameters constant is shown in Table V. Proper temperature for dissolution and electro-deposition is required since at either high temperature $\left(120^{\circ} \mathrm{C}\right)$ or low temperature $\left(60^{\circ} \mathrm{C}\right)$ the current efficiency stay relatively low and energy consumption stay relatively high, which compared to the result obtained from $100^{\circ} \mathrm{C}$. Meanwhile, amount of zinc oxide addition in the solution has an impact on the experimental result which reflects on the current efficiency and energy consumption. It is suggesting that a specific amount of zinc oxide addition which in this experiment is $2.0 \mathrm{~g}$ in the solution will reach in higher efficiency of current and hence lower energy consumption. Moreover, more negative potential (-1.9V) will result in a higher utilization of current and thus lower energy consumption. 
Table IV. Experimental results calculated for $0.3 \mathrm{~g} \mathrm{PbO}$ in $30 \mathrm{~mL}$ urea based ionic liquid which conducted for $\mathrm{t}=0.5 \mathrm{hr}, 1 \mathrm{hr}$ for fixed potential $\mathrm{E}_{1}^{\mathrm{o}}=-1.8 \mathrm{~V}$ and $\mathrm{E}_{2}^{\mathrm{o}}=-2.0 \mathrm{~V}$, in a solution with a constant stirring rate, at a temperature of $90^{\circ} \mathrm{C}$

\begin{tabular}{llllll}
\hline $\begin{array}{l}\text { Experimental } \\
\text { Number }\end{array}$ & $\begin{array}{l}\text { Time } \\
(\mathbf{h})\end{array}$ & $\begin{array}{l}\text { Potential } \\
(\mathbf{V})\end{array}$ & $\begin{array}{l}\Delta \mathbf{W} \\
(\mathbf{g})\end{array}$ & $\begin{array}{l}\mathbf{W}_{\mathbf{T}} \\
(\mathrm{g})\end{array}$ & Efficiency \\
\hline 1 & 6.0 & -1.8 & 0.1932 & 0.2229 & $86.7 \%$ \\
2 & 1.0 & -2.0 & 0.2270 & 0.3300 & $68.7 \%$ \\
3 & 1.0 & -1.8 & 0.2100 & 0.3200 & $65.6 \%$ \\
4 & 0.5 & -2.0 & 0.0220 & 0.0300 & $73.3 \%$ \\
5 & 0.5 & -1.8 & 0.0129 & 0.0160 & $80.6 \%$ \\
\hline
\end{tabular}

Table V. Current efficiency calculation of zinc oxide for different parameters, $\mathrm{E}^{\mathrm{o}}=-1.6 \mathrm{~V},-1.7 \mathrm{~V}$, and $-1.9 \mathrm{~V}$; amount $=1.0 \mathrm{~g}, 2.0 \mathrm{~g}$, and $3.0 \mathrm{~g}$; temperature $=60^{\circ}, 100^{\circ}$, and $120^{\circ}$, fixed time at 4 hours in a non-stirring solution

\begin{tabular}{ccccc}
\hline $\begin{array}{c}\text { Experimental } \\
\text { Number }\end{array}$ & $\begin{array}{c}\text { Temperature } \\
\left({ }^{\circ} \mathbf{C}\right)\end{array}$ & $\begin{array}{c}\text { Potential } \\
(\mathbf{V})\end{array}$ & $\begin{array}{c}\text { Amount } \\
(\mathbf{g})\end{array}$ & Efficiency \\
\hline 1 & 120 & -1.6 & 2.0 & $80.29 \%$ \\
2 & 100 & -1.6 & 1.0 & $90.96 \%$ \\
3 & 100 & -1.6 & 2.0 & $91.47 \%$ \\
4 & 100 & -1.6 & 3.0 & $83.26 \%$ \\
5 & 60 & -1.8 & 2.0 & $73.26 \%$ \\
6 & 90 & -1.7 & 2.0 & $86.49 \%$ \\
7 & 90 & -1.9 & 2.0 & $95.67 \%$ \\
\hline
\end{tabular}

X-ray diffraction (XRD) analysis was carried out on the deposits obtaining in Figure 9a and Figure $9 \mathrm{~b}$. The results were shown in Figure 11a and Figure $11 \mathrm{~b}$. The resulting pattern was compared with the standard ICDD card. Lead signals were detected in XRD spectra at $30^{\circ}, 35^{\circ}$, $50^{\circ}, 60^{\circ}, 76^{\circ}, 84^{\circ}, 87^{\circ}, 98^{\circ}$, and $106^{\circ}$ on the copper substrate while zinc signals were detected in XRD spectra at $34^{\circ}, 37^{\circ}, 42^{\circ}, 54^{\circ}, 69^{\circ}, 81^{\circ}, 86^{\circ}, 89^{\circ}$, and $94^{\circ}$ on the aluminum substrate. The XRD pattern confirms the deposition of pure lead and zinc on cathode. 


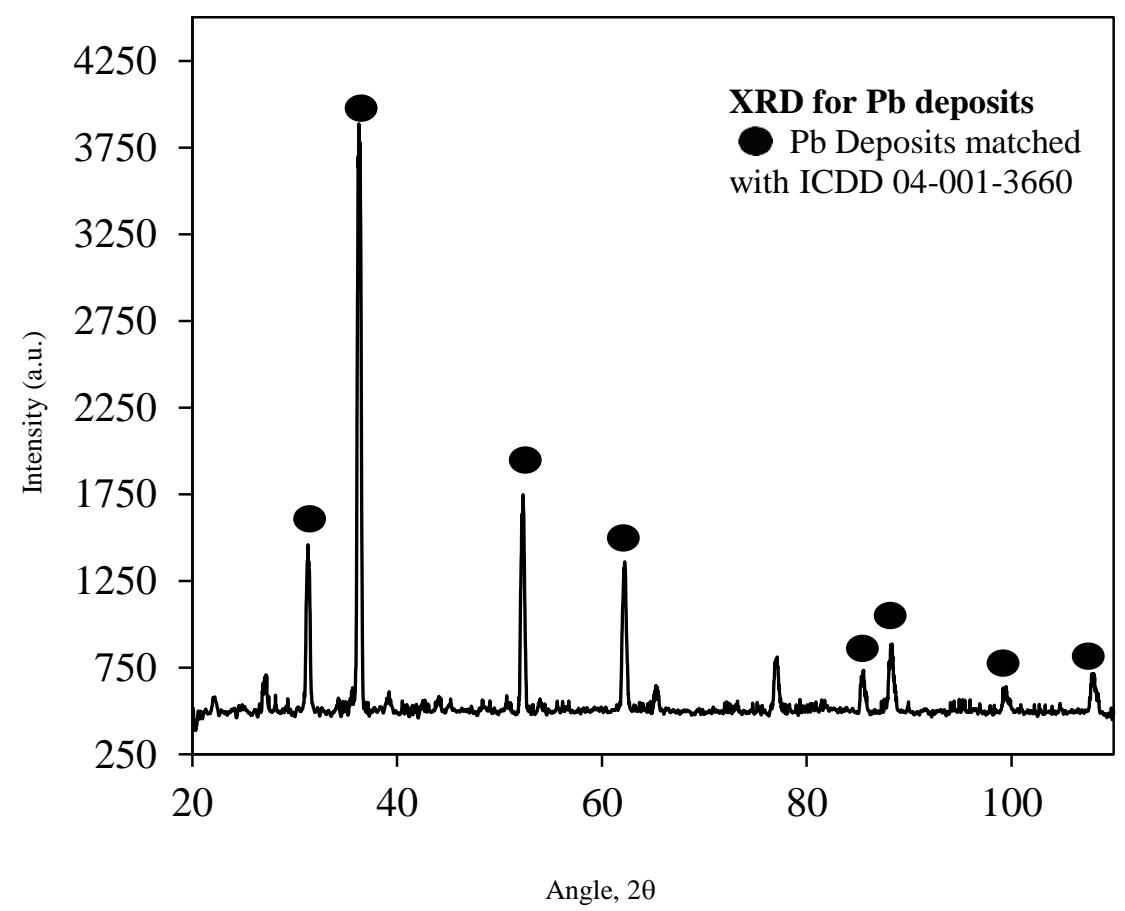

Figure 11a: X-ray diffraction (XRD) pattern for Lead deposits on copper working electrode

Deposition of lead from urea and choline chloride based ionic liquid results in a negligible residual chloride on the metal surface which shows in the bright area of the image in the Figure 12a. The results show the deposition collecting from ionic liquid in a rod-like structure with an average diameter of about $1 \mu \mathrm{m}$ and length of up to $200 \mu \mathrm{m}$ predicting from the first image in figure 12a. The dentritic clusters are made of cubic crystals, as seen in the last three images which magnified by 2000x and 4000x. Energy Dispersive Electron (EDS) analysis confirms that they are dominantly made of elemental lead and only slight few amount of chloride. 


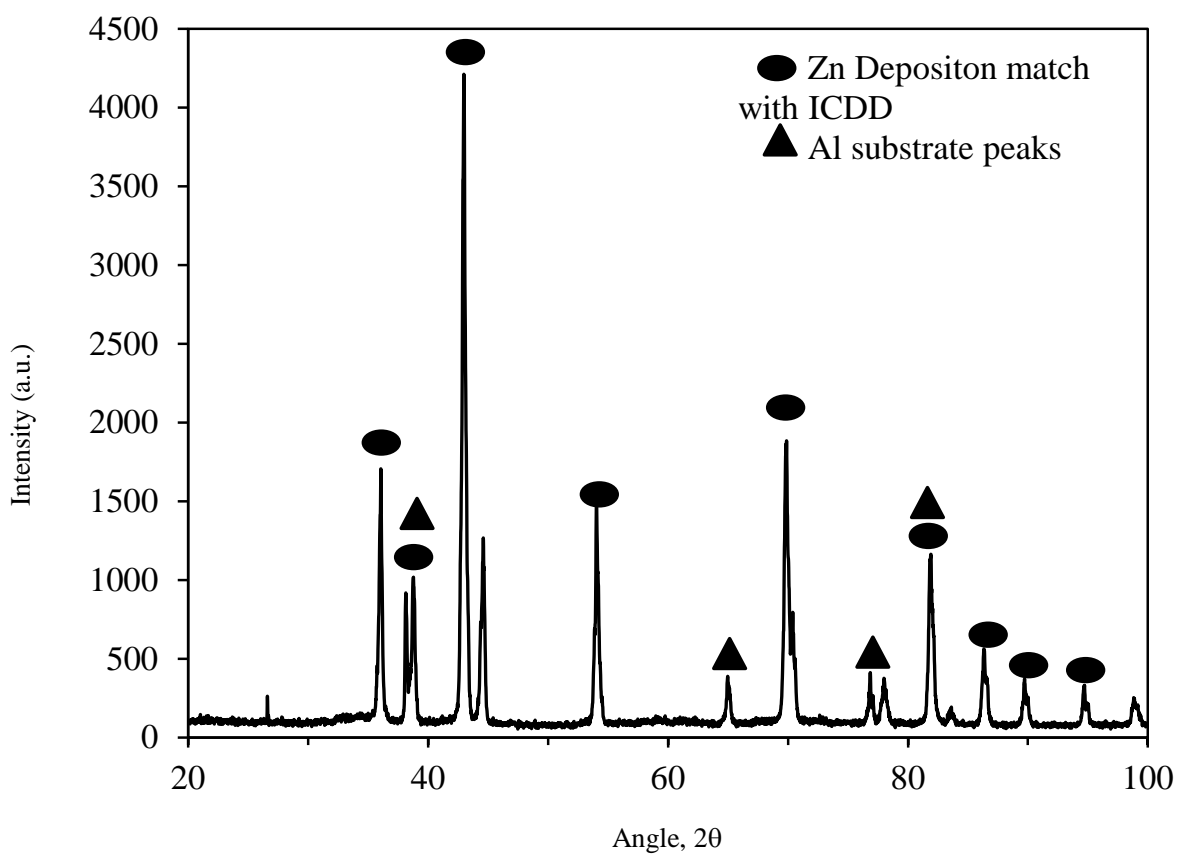

Figure 11b: X-ray diffraction (XRD) pattern for Zinc deposits on Aluminum sheet working electrode
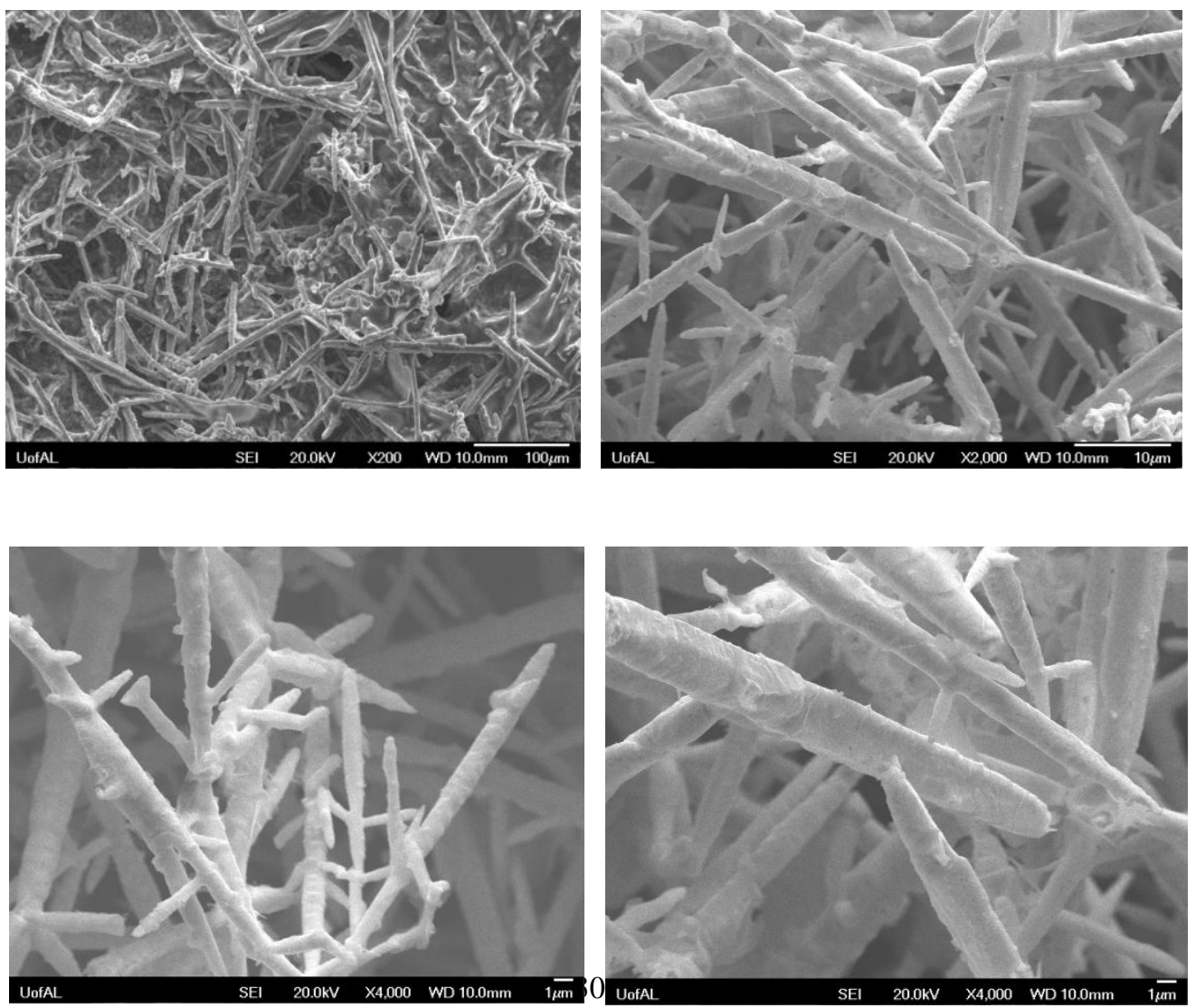


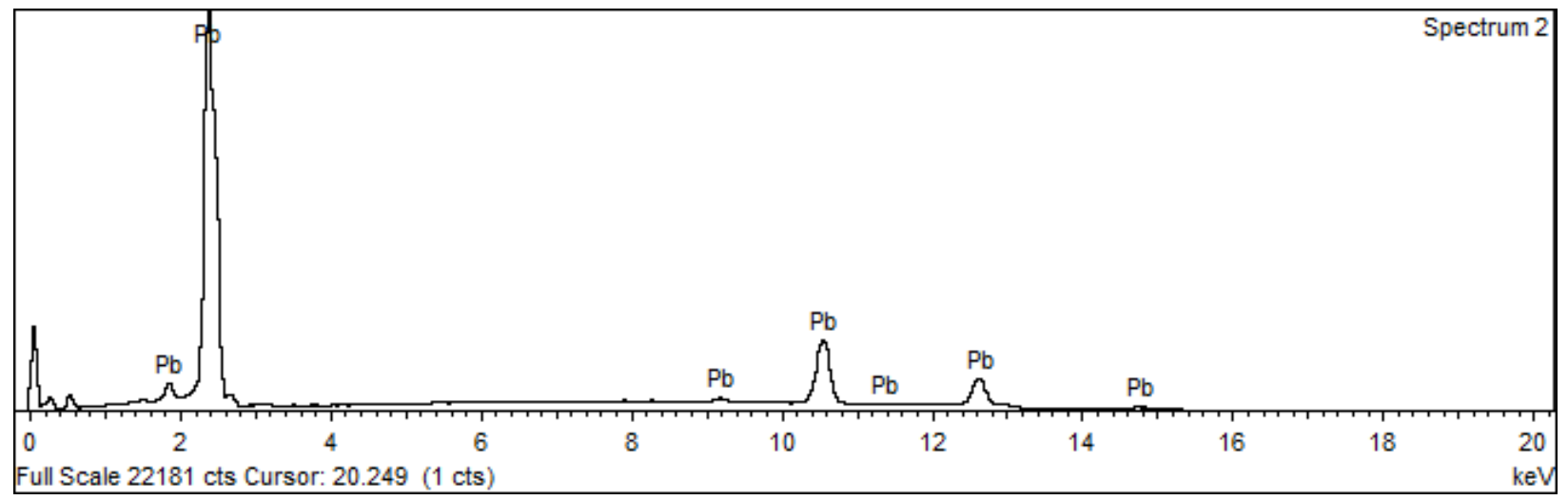

Figure 12a: Scanning Electron Microscopy showing different region of the lead deposits on $\mathrm{Cu}$ foil obtained from a molar ratio of 2:1 urea and choline chloride eutectic mixture and Energy

Dispersive Electron analysis of the lead deposits

Figure 12b shows the SEM image of the zinc deposited from urea and choline chloride based ionic liquid. The bright area in the image is caused by residual chloride attached on the metal surface. The average size of the deposited particulate $\mathrm{Zn}$ is about $20 \mu \mathrm{m}$. In a low magnitude, the zinc deposits exhibit a granular morphology, as seen in the first two images which magnified by 100x and 800x. In order to view the clear surface of the particle, higher magnitude image was being showed in the last two images which magnified by 2000x and 6400x. It is reported herein the deposition of zinc is made up by many dendrite clusters. The dendrites are built up of crystallike structure. The EDS analysis of the deposits confirms that elemental zinc was obtained regardless of traces of oxidized zinc which is due to the over-exposure in the air.
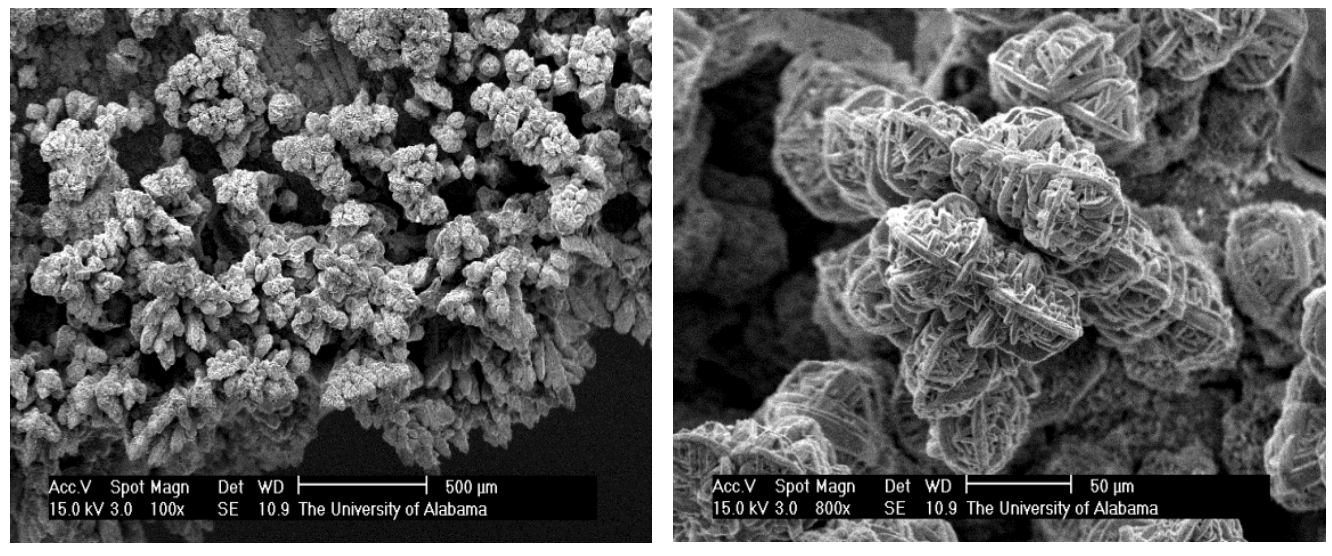

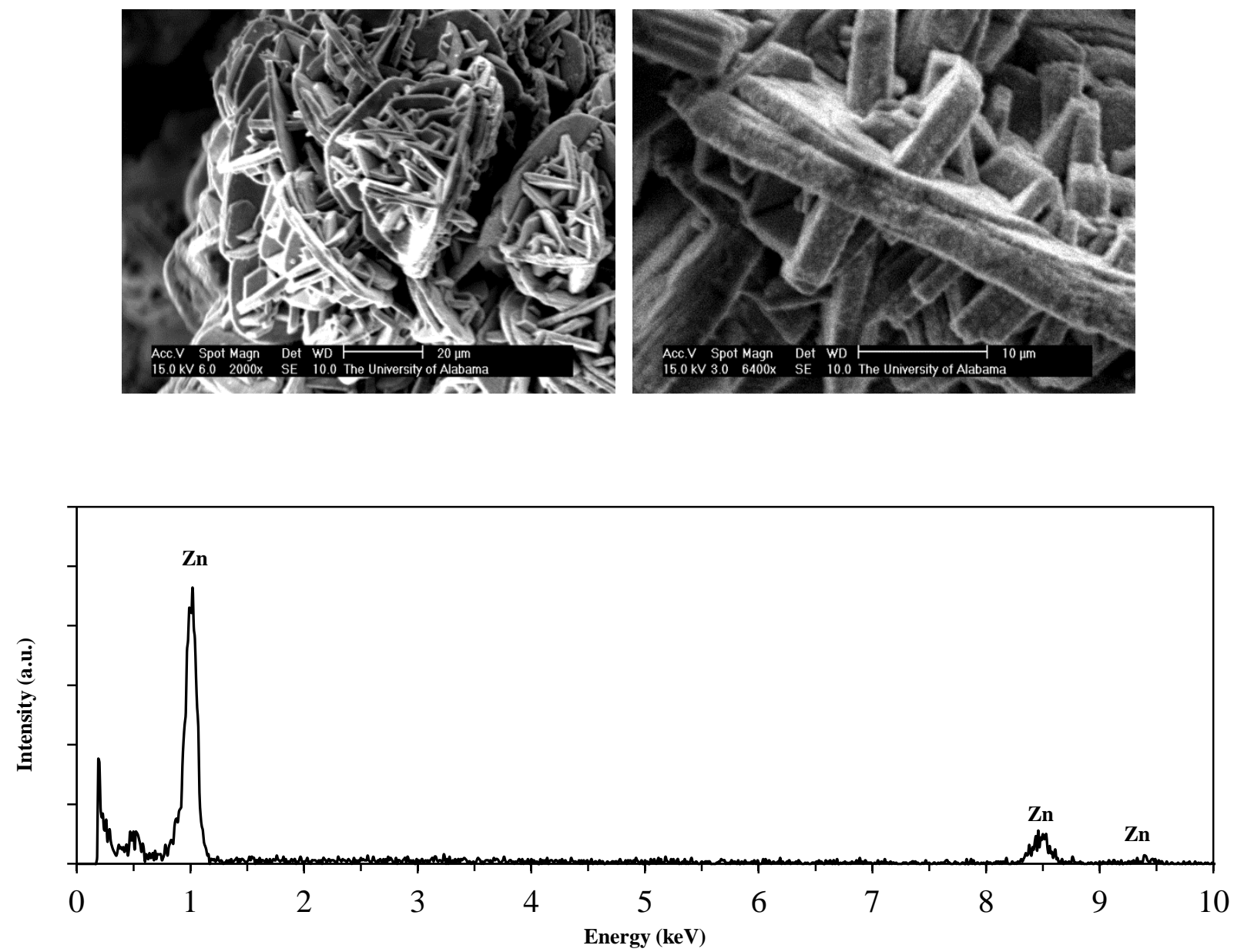

Figure 12b: SEM micrograph of the zinc deposits in different region on aluminum sheet grown from 2:1 molar ratio of urea and choline chloride eutectic mixture and Energy Dispersive Electron analysis of zinc deposits 


\section{Accomplishments}

Table VI: Comparison of the actual accomplishments with the goals and objectives of the project

\begin{tabular}{|l|l|l|}
\hline S1. No. & Goals and objectives & Actual accomplishments \\
\hline 1 & $\begin{array}{l}\text { Determination of suitable ionic } \\
\text { liquid system }\end{array}$ & $\begin{array}{l}\text { Many ionic liquids were investigated } \\
\text { based on their properties and the } \\
\text { eutectic mixture of urea and choline } \\
\text { chloride in a 2:1 molar ratio was } \\
\text { selected. }\end{array}$ \\
\hline 2 & $\begin{array}{l}\text { Dissolution of metal oxide (MO) in } \\
\text { ionic liquid }\end{array}$ & $\begin{array}{l}\text { Successful dissolution of MO in the } \\
\text { ionic liquid was achieved. To } \\
\text { understand the solubility limit and the } \\
\text { optimum conditions, several parameters } \\
\text { such as time, temperature and amount of } \\
\text { metal oxide were tested. }\end{array}$ \\
\hline 3 & $\begin{array}{l}\text { Determination of reduction } \\
\text { potential using cyclic voltammetry } \\
\text { (CV) }\end{array}$ & $\begin{array}{l}\text { CV was used successfully to determine } \\
\text { the reduction potential of metal ion to } \\
\text { metal in the ionic liquid solution. Effect } \\
\text { of different scan rates and use of } \\
\text { different working electrodes were } \\
\text { determined. This helped in the design of } \\
\text { electro-deposition experiments. }\end{array}$ \\
\hline 4 & $\begin{array}{l}\text { Electro-deposition of metals, namely, Pb } \\
\text { and Zn were successfully carried out } \\
\text { from PbO and ZnO, respectively using } \\
\text { choline chloride based ionic liquid. } \\
\text { Effect of change in temperature, stirring, } \\
\text { time, reduction potential and the amount } \\
\text { of metal oxide dissolved on the current } \\
\text { efficiency of the process has been } \\
\text { experimentally determined. }\end{array}$ \\
\hline
\end{tabular}

Products developed and technology transfer activities:

a. publications:

Research Paper:

R. G. Reddy, Low Temperature production of zinc from zinc oxide, Carbon Management Technology Conference, CMTC 151684 PP, Orlando, FL, pp. 1-6, 2012.

M.S. Thesis:

H. Yang, Zinc and Lead Oxide Extraction from Urea and Choline Chloride Eutectic Mixture, M.S. Thesis, The University of Alabama, Tuscaloosa, Alabama (in progress) 
b. Website:

N/A

c. Networks or collaborations fostered:

N/A

d. Technologies/Techniques:

N/A

e. Inventions/Patent Applications, licensing agreements:

N/A

f. Other products:

N/A

\section{Conclusions}

This paper investigates that eutectic mixture of choline chloride and a hydrogen bond donor e.g. urea in this case can be properly used as a solvent for metal extraction. Solubility of lead and zinc oxides in a 2:1 molar eutectic mixture of urea/choline chloride ionic liquid has been measured by using Fourier Transform Infrared Spectroscopy. The electro-deposition of metal from metal oxide using the ionic liquid has been studied. Electro-deposition was carried out in the potential range of $-0.6 \mathrm{~V}$ to $-1.9 \mathrm{~V}$ for the reduction of lead oxide and $-1.4 \mathrm{~V}$ to $-1.9 \mathrm{~V}$ for the reduction of zinc oxide. The current efficiency for the deposition of $\mathrm{Pb}$ and $\mathrm{Zn}$ obtained was about $86 \%$ and $96 \%$ respectively. The deposits were analyzed using XRD and SEM-EDS. The results from XRD confirm the deposition of phase pure metal on the cathode. The morphology of the deposited product is rod-like structure with an average diameter of $1 \mu \mathrm{m}$ and up to $200 \mu \mathrm{m}$ in length in the case of lead and particles of about $20 \mu \mathrm{m}$ in size in the case of zinc. Successful extraction of lead and zinc from lead oxide and zinc oxide using ionic liquid was accomplished. 


\section{Recommendations}

The dissolution and reduction of lead and zinc oxides to their respectively metals has been successfully carried out using choline chloride / urea based ionic liquid. The same conceptual basis can be extended to other oxide systems and the author(s) recommend the following:

- Reduction of other oxide systems such as $\mathrm{TiO}_{2}, \mathrm{SiO}_{2}, \mathrm{Al}_{2} \mathrm{O}_{3}, \mathrm{MgO}$, etc. is highly recommended. These oxide systems will present a challenge due to their high stability.

- Testing of other ionic liquid systems, estimation of their properties and dissolution of oxides in them will offer wider stability range for reduction.

- Design of electrolytic cell for commercial synthesis for the reduction of metal oxides is also recommended.

\section{References}

[1] B. Cornils, W.A. Herrmann, in: B. Cornils, W.A. Herrmann (Eds.), Aqueous Phase Organometallic Catalysis - Concept and Applications, Wiley/VCH, Weinheim, 1998.

[2] P.G. Jessop, T. Ikariya, R. Noyori, Chem. Rev., 99 (1999), p. 475

[3] A.P. Abbott, J. C. Barron and K. S. Ryder, "Electrolytic deposition of Zn coatings from ionic liquids based on Choline Chloride”, Trans. Inst. Metal Finishing, 87(4), pp.201-207,2009.

[4] S.N.V.K. Aki, J.F. Brennecke, A. Samanta, Chem. Commun. (2001) 413.

[5] F. Endres, A. P. Abbott and D. MacFarlane, Electrodeposition using Ionic Liquids, Wiley VCH, Weinheim, 2008

[6] R. T. Carlin and J. S. Wilkes, "Chemistry of Non-aqueous Electrochemistry," D. Aurbach, Editor, Marcel Dekker, New York, pp. 461,1999.

[7] A.P. Abbott, G. Capper, D.L. Davies, R.K. Rasheed, V. Tambyrajah, Chem. Commun. (2003), p. 70

[8] A.P Abbott, Phys. Chem. Chem. Phys. 2006, 8, 4265-4279

[9] A. P Abbott, G. Capper, D. L Davies, H. Munro, R. K Rasheed and V. Tambyrajah, Chem. Commun., 2001, 2010

[10] Colthup, N. B.; Daly, L. H.; Wiberley, S. E. Introduction to Infrared and Raman Spectroscopy, 3rd ed; Academic Press: New York,1990.

[11] M. Noel, K.I. Vasu, Cyclic Voltammetry and the Frontiers of Electrochemistry, Aspect Publications Ltd, London (1990). 